\title{
ARTICLES \\ QUANTITATIVE PROOF OF REPUTATIONAL HARM
}

\author{
Meiring De Villiers
}

\begin{abstract}
Economists have advocated, and courts have accepted a decline in the stock price of a defamed corporation as an economic measure of its reputational harm. Although the economic rationale for this approach is sound and widely accepted, its legal foundations and consistency with the damages doctrines of defamation law have remained unexplored. This article presents an analysis of its legal basis. The analysis shows that the logic of common law precedent, supported by statutes and academic commentary, points to a measure of special damages for reputational harm based on stock market data
\end{abstract}

\section{INTRODUCTION}

The law of defamation aims to protect a plaintiff's reputation and provide compensation where it has been harmed. Most defamation actions are brought by individuals, ${ }^{1}$ but courts have extended the protection of defamation law to the reputational interests of corporations. A corporation has no reputation in a personal sense, but it has standing in the business in which it operates. It can therefore sue for defamatory statements related to matters affecting its business reputation, such as financial soundness and managerial integrity. ${ }^{2}$

The category of damages known as special damages, compensates the defamation plaintiff for financial loss flowing directly from reputational injury caused by a defamatory publication. ${ }^{3}$ Economists

1. See, e.g., Marc A. Franklin, Winners and Losers and Why: A Study of Defamation Litigation, 3 AM. B. FOUND. RES. J. 455, 478 (1980).

2. See infra notes $18-21,30,41,57,58,61,86,142,163,175,178,180,202,205$, 209.

3. See, e.g., I Robert D. SACK, SACK ON Defamation: Libel, Slander, AND RELATED Problems $\S 10.3 .2$ (Practising Law Inst., 3d ed. 2008) ("Special damages are damages awarded to compensate the plaintiff for actual pecuniary loss . . . [which] comprising special damages must flow directly from the injury to reputation caused by 
have advocated, and courts have accepted a decline in the stock price of a publicly traded defamed corporation as evidence of special damages. ${ }^{4}$ Although the economic rationale for this approach is sound and widely accepted, its legal foundations and consistency with the damages doctrines of defamation law have remained unexplored. This article presents an analysis of its legal basis. It shows that the logic of common law precedent, supported by statutes and academic commentary, points to a measure of special damages for reputational harm based on stock market data.

An analysis of the legal concept of corporate reputation and its relation to the intangible corporate asset known as goodwill, shows that the law recognizes (i) a systematic causal relationship between reputational harm and loss of goodwill, and (ii) that loss of goodwill is reflected in a decline in the value of the shares of the corporation. The decline in the value of the securities of a defamed corporation, adjusted for factors unrelated to the defamation, therefore constitutes legally valid evidence of special damages for its reputational injury. The adjustment for extraneous factors is necessary to satisfy the proximate cause doctrine of tort law. ${ }^{5}$

The Article is organized as follows. Section 2 reviews the principles of defamation, including damages. Section 3 analyzes the legal definition of corporate reputation and its relation to goodwill. Section 4 reviews the legal, accounting, and economic definitions of goodwill. It concludes that the modern legal view of goodwill has adopted the accounting and economic meanings. Section 5 combines the results from preceding sections and argues the legal validity of a capital market approach to proving and quantifying special damages in corporate defamation. A final section concludes.

\section{Principles of Defamation}

The tort of defamation is an invasion of the interest of a person or corporation in its reputation and good name. ${ }^{6}$ Defamation law allows a

the defamation.").

4. See infra note 41 .

5. The adjustment for extraneous factors is necessary to satisfy the proximate cause doctrine of tort law. See infra notes 210-11, 213-16.

6. See, e.g., I SACK, supra note 3, $\S 2.4 .1$ ("Defamation deals with expression ... that injures reputation." (citing Smith v. Maldonado, 85 Cal. Rptr. 2d 397, 402 (1999) (stating that "[d]efamation is an invasion of the interest in reputation"))). See also 
plaintiff to restore her reputation and obtain compensation for harm caused by defamatory statements. ${ }^{?}$

A defamatory statement is a statement of fact about a person or business entity that tends to diminish the plaintiff's reputation. ${ }^{8}$ It has, for instance, been held to be defamatory to say that a person is a credit risk, ${ }^{9}$ that a kosher meat dealer has sold bacon, ${ }^{10}$ and that a physician has advertised. ${ }^{11}$

A person or corporation can be defamed by more than written or spoken words. ${ }^{12}$ Defamation may occur by means of a picture, a

RESTATEMENT (SECOND) OF TORTS $§ 559$ (1977) (stating that defamation is the broader term for libel and slander. Libel is concerned with written or printed words, or more generally, embodiment of the defamatory message in tangible or permanent form. Slander constitutes oral defamation); William L. Prosser et AL., Prosser AND KEETON'S HORNBOOK ON TORTS $§ 112$, at 785-88 (5th ed. 1984).

7. See Milkovich v. Lorain Journal Co., 497 U.S. 1, 12 (1974) ("Defamation law developed not only as a means of allowing an individual to vindicate his good name, but also for the purpose of obtaining redress for harm caused by such statements."); Gertz v. Robert Welch, Inc., 418 U.S. 323, 348 (1974) (explaining that there is a "strong and legitimate state interest in compensating private individuals for injury to reputation."). See also Arlen W. Langvardt, A Principled Approach to Compensatory Damages in Corporate Defamation Cases, 27 AM. BUS. L.J. 491, 494 (1990) (stating that the definition of the tort of defamation "reflects the major concern underlying the development of the defamation cause of action: the protection and vindication of the plaintiff's reputation").

8. See, e.g., RESTATEMENT (SECOND) OF TORTS $\S \S 558,559$ (1977) ("A communication is defamatory if it tends so to harm the reputation of another as to lower him in the estimation of the community or to deter third persons from associating or dealing with him."); Jessica R. Friedman, Defamation, in Report, A Lawyer's Ramble Down the Information Superhighway, 64 FORDHAM L. REV. 697, 794 (1995) ("A defamatory statement is a false statement of fact about a living person, corporate entity, or other business unit that tends to injure his or its reputation or the esteem, respect, or goodwill in which the subject is held by a substantial and respectable group of people.").

9. See, e.g., Dun \& Bradstreet, Inc. v. Greenmoss Builders, Inc., 472 U.S. 749 (1985) (holding that a showing of actual malice was not necessary for plaintiff to recover presumed and punitive damages for false statements in a credit report); Neaton v. Lewis Apparel Stores, 48 N.Y.S.2d 492 (N.Y. App. Div. 1944) (holding valid a plaintiff's complaint for defamation with regard to his credit).

10. See, e.g., Braun v. Armour \& Co., 173 N.E. 845 (N.Y. 1930) (holding that it was libelous to represent that a dealer in kosher meat sold bacon, a nonkosher product).

11. See, e.g., Gershwin v. Ethical Publ'g Co., 1 N.Y.S.2d 904 (N.Y. City Ct. 1937) (holding that an article falsely attributing the use of colloidal sulphur to a reputable physician was per se libelous).

12. See, e.g., Restatement (SECOND) OF TORTS $\S 565$, cmt. b (1977) ("To be 
gesture, a loaded question, or an insinuation. ${ }^{13}$ The defamatory imputation may be indirect. Signing the plaintiff's name to false ${ }^{14}$ or bad authorship, ${ }^{15}$ for instance, has been held to be defamatory. Modern technology occasionally generates false alarms, such as a false positive mammogram, sobriety test, or HIV test, which may cause emotional distress, and in some cases actionable reputational harm. ${ }^{16}$ A false positive drug test, for instance, may wrongly imply that the test subject is a drug abuser. ${ }^{17}$

Courts have extended the protection of defamation law to the reputational interests of corporations. ${ }^{18}$ Although a corporation has no

defamatory ... it is not necessary that the accusation or other statement be by words. It is enough that the communication is reasonably capable of being understood as charging something defamatory."). See also Defamation Act, 1996, c. 31, §17(1) (Eng.) (stating that a defamatory statement means "words, pictures, visual images, gestures or any other method signifying meaning").

13. See Rodney A. Smolla, LaW of Defamation $\S \S 4: 1,4: 4$ (2d ed. 2006).

14. See, e.g., Masson v. New Yorker Mag., Inc., 501 U.S. 496, 517 (1991) (holding that an altered quotation may be actionable if it conveys a substantially false and defamatory meaning); Locke v. Benton \& Bowles, Inc., 1 N.Y.S.2d 240 (N.Y. Sup. Ct. 1937), rev'd, 2 N.Y.S.2d 150 (N.Y. App. Div. 1938) (denying defendant's motion to dismiss the complaint for damaging plaintiff's reputation as a reporter); Ben-Oliel $v$. Press Publ'g Co., 167 N.E. 432 (N.Y. 1929) (holding that it is not necessary for defendant to directly attack plaintiff in its paper to constitute libel).

15. See, e.g., Sperry Rand Corp. v. Hill, 356 F.2d 181 (1st Cir. 1966) (holding that the question of libel was sufficient for a jury on the issue of false authorship); Carroll v. Paramount Pictures, 3 F.R.D. 47 (S.D.N.Y. 1943) (denying defendant's motion for summary judgment to dismiss plaintiff's actions against a production company based on alleged fact that defendant released a motion picture bearing false representation that it was produced by the plaintiff).

16. See, e.g., Meiring de Villiers, Opinionated Software, 10 VAND. J. ENT. \& TECH. 269 (2008) (analyzing computer virus false alarm as a defamatory statement of fact).

17. See Nehrenz v. Dunn, 593 So. 2d 915 (La. Ct. App. 1992) (describing the circumstances of an prospective employee who was rejected for employment following from a lab report which indicated that he had a controlled substance within his system); Lewis v. Aluminum Co. of Am., 588 So. 2d 167, 170 (La. Ct. App. 1991). But see Karen Manfield, Comment, Imposing Liability on Drug Testing Laboratories for "False Positives": Getting Around Privity, 64 U. CHI. L. REV. 287, 299-302 (1997) (explaining that "courts have disagreed about whether a testing laboratory owes a general duty of reasonable care to . . . workers"); Thomas L. McGovern III, Note, Employee Drug-Testing Legislation: Redrawing the Battlelines in the War on Drugs, 39 STAN. L. REV. 1453, 1458-59 (1987) (discussing settlement of negligence action against testing laboratory by two job applicants whose applications were rejected due to false positive tests for marijuana).

18. See, e.g., Nat'l Ref'g Co. v. Benzo Gas Motor Fuel Co., 20 F.2d 763, 766 (8th 
reputation in the personal sense of an individual, ${ }^{19}$ it has standing in the business in which it operates. ${ }^{20}$ It can therefore sue and recover damages for defamatory statements related to matters affecting its business reputation and practices, such as financial soundness, management and efficiency. ${ }^{21}$

Cir. 1927); RESTATEMENT (SECOND) OF TORTS $\S 561 \mathrm{cmt}$. b (1977) ("A corporation for profit has a business reputation and may therefore be defamed . ..."); HARRY G. HENN ET AL., HANDBOOK OF THE LAW OF CORPORATIONS AND OTHER BUSINESS ENTERPRISES $\S 80$, at 112 (2d ed. 1970); Prosser ET AL., supra note 6, $\$ 111$, at 779; Patricia Nassif Fetzer, The Corporate Defamation Plaintiff as First Amendment 'Public Figure': Nailing the Jellyfish, 68 IowA L. REV. 35, 53 (1982); Langvardt, supra note 7, at 496 ("[P]ermissible plaintiffs in defamation suits include corporations as well as natural persons." (citing Brown \& Williamson Tobacco Corp. v. Jacobson, 827 F.2d 1119, 1139 n.10 (7th Cir. 1987))).

19. See, e.g., Langvardt, supra note 7, at 496 ("Corporations long have been considered proper plaintiffs even though they cannot experience the humiliation, emotional distress, and personal indignities that may be endured by a natural person."). See also Golden Palace, Inc. v. NBC, 386 F. Supp. 107, 109 (D.D.C. 1974) (holding that while a corporation may maintain an action for libel, it has no personal reputation); DiGiorgio Fruit Corp. v. AFL-CIO, 30 Cal. Rptr. 350, 355-56 (Cal. Dist. Ct. App. 1963); Reporters' Ass'n of Am. v. Sun Printing \& Publ'g Ass'n, 79 N.E. 710 (N.Y. 1906) (holding that a corporation has the right to maintain a libel action); Robert $\mathrm{E}$. Dreschel et al., Corporate Libel Plaintiffs and the News Media: An Analysis of the Public-Private Figure Distinction After Gertz, 21 AM. Bus. L.J. 127, 138 (1983); Perry Herzfeld, Corporations, Defamation and General Damages: Back to First Principles, 10 MEDIA \& ARTS L. REV. 135, 139 (2005) ("[A] corporation cannot recover damages for injury to feelings as a 'company cannot be injured in its feelings." (citing Lewis v. Daily Telegraph Ltd., (1964) A.C. 234, 262 (Eng.))).

20. See, e.g., Di Giorgio Fruit Corp., 30 Cal. Rptr. at 355-56; Prosser ET AL., supra note $6, \S 111$ at 779 ("A corporation is regarded as having no reputation in any personal sense ... [b]ut it has prestige and standing in the business in which it is engaged, and language which casts an aspersion upon its honesty, credit, efficiency or other business characteristic may be actionable.").

21. See Dun \& Bradstreet, Inc. v. Greenmoss Builders, Inc., 472 U.S. 749 (1985) (stating that false credit report reflected negatively on firm's solvency); Brown \& Williamson Tobacco Corp., 827 F.2d at 1138 (stating that a corporation has protectable business reputation centering around notions of integrity); Axton Fisher Tobacco Co. v. Evening Post Co., 183 S.W. 269 (Ky. 1916) (permitting defamation of corporation by reflection upon its business methods); GTP Leisure Prods. v. B-W Footwear Co., 391 N.Y.S.2d 489 (N.Y. App. Div. 1977) (stating that defamation of corporation reflects upon its credit); RESTATEMENT (SECOND) OF TORTS $\S 561 \mathrm{cmt}$. b, ill. 3 (publication which reflects negatively on the credit or business methods of a corporation has defamed the corporation). See also Diplomat Elec., Inc. v. Westinghouse Elec. Supply Co., 378 F.2d 377 (5th Cir. 1967) (holding actionable materialman's statements to third parties about a subcontactor's delinquent account); Aetna Life Ins. Co. v. Mut. Benefit 


\section{Elements}

The complexity of the tort of defamation is illustrated by the elements that have to be satisfied to establish a cause of action. One author has identified nine elements, ${ }^{22}$ while another lists twenty three, ${ }^{23}$ each crucial to a defamation action. The defamation plaintiff must plead and prove the following elements: ${ }^{24}$

1. The statement of fact must be published to a third party other than the plaintiff. ${ }^{25}$

2. The statement must be false.

3. The statement must be defamatory, in other words, harmful to the reputation of the plaintiff.

4. The statement must have reasonably referred to the plaintiff.

5. The defendant must have acted with the requisite degree of fault.

The fault requirement depends on the plaintiff's status. A privatefigure plaintiff must prove negligence, namely that, by a preponderance of the evidence, the defendant lacked reasonable grounds for believing the statement to be true, or failed to take reasonable care to ascertain the truth. A public plaintiff ${ }^{26}$ must

Health \& Accident Ass'n, 82 F.2d 115, 120 (8th Cir. 1936) (holding that a corporation can maintain a libel action for a publication assiling its management or credit); Maytag Co. v. Meadows Mfg. Co., 45 F.2d 299, 302 (7th Cir. 1930) (holding that "where a libel contains an imputation upon a corporation in respect to its business, its ability to do business, and its methods of doing business, the same becomes libelous per se"); $D i$ Giorgio Fruit Corp., 30 Cal. Rptr. at 355-56; RESTATEMENT (SECOND) OF TORTS $§ 561$ (1976); Milo Geyelin, Corporate Mudslinging Gets Expensive-Aggrieved Do More Than Turn Other Cheek, WALl ST. J., Aug. 4, 1989, at B1.

22. See Robert D. Nelon, Media Defamation in Oklahoma: A Modest Proposal and New Perspectives-Part I, 34 OKLA. L. REV. 478, 488 (1981) ("[N]ine discrete but interrelated elements accurately describe the constitutional boundaries of the tort and place the remaining common law aspects of libel in their proper perspective.").

23. See W. Page Keeton, Defamation and Freedom of the Press, 54 TEX. L. REV. 1221, 1233-35 (1976).

24. See SMOLLA, supra note 13, § 1:34; Friedman, supra note 8, at 794.

25. See Prosser ET AL., supra note 6, $\S 111$, at 774 (" $[\mathrm{I}] \mathrm{t}$ is enough that the communication would tend to prejudice the plaintiff in the eyes of a substantial and respectable minority, but in such a case it must be shown that the communication did reach one or more persons of that minority group.").

26. "Public plaintiff' includes a public official, N.Y. Times v. Sullivan, 376 U.S. 254 (1964), a public figure, Curtis Publishing Co. v. Walker, 388 U.S. 130 (1967), and a limited purpose public figure, Gertz v. Robert Welch, Inc., 418 U.S. 323, 345 (1974). Limited purpose public figures are people who "have thrust themselves to the forefront 
prove by clear and convincing evidence that the defendant published the statement with "actual malice." Actual malice is defined as "with knowledge that the statement was false, or with reckless disregard of whether it was false or not.",27

6. The statement must be objectively capable of being proven materially false. ${ }^{28}$

7. The statement must have caused actual harm to the plaintiff.

8. The statement must not be privileged, as a privileged publication is not actionable. Judges, attorneys, jurors, and legislators, for instance, can plead an absolute privilege for statements made in furtherance of their official duties. ${ }^{29}$

\section{Damages}

A corporate plaintiff may recover presumed damages and special damages. ${ }^{30}$ Under the presumed damages rule, no proof of reputational harm is required. Harm is presumed and the fact finder may assess an amount it deems appropriate. ${ }^{31}$ The plaintiff may augment its damages recovery by providing evidence of special damages, but is not required to do so. ${ }^{32}$

Courts often award substantial amounts in presumed damages, even in the absence of proof of actual reputational harm. In Brown \& Williamson Tobacco Corp. v. Jacobson, ${ }^{33}$ the jury awarded the plaintiff

of particular public controversies in order to influence the resolution of the issues involved." Gertz, 418 U.S. at 345. The "public official" category is fairly wide, and includes, for instance, government employees. See I SLADE R. METCALF, RIGHTS AND LIABILITIES OF PUBLISHERS, BROADCASTERS, AND REPORTERS $\S 1: 50$ (1982).

27. N.Y. Times, 376 U.S. at 279-80.

28. Under the constitutional standard articulated by the Supreme Court in Milkovich, statements that are not objectively verifiable, or that do not contain a provably false connotation, are entitled to full First Amendment protection. Milkovich v. Lorain Journal Co., 497 U.S. 1, 19 (1974).

29. See, e.g., I SACK, supra note $3, \S \S 8.2 .1 .2,8.2 .1 .3,8.2 .1 .5,8.2 .2$.

30. See, e.g., SMOLLA, supra note 13, $\S 9: 16,9: 35$. See also Langvardt, supra note 7, at 497-98; Norman Redlich, Corporate Defamation Symposium: The Publicly Held Corporation as Defamation Plaintiff, 39 ST. LoUIS U. L.J. 1167, 1173-74 (1995).

31. See, e.g., Redlich, supra note 30, at 1174. For a discussion of the types of cases that allow presumed damages, see Langvardt, supra note 7, at 498-99.

32. See SMOLLA, supra note 13, § 9:35 ("Special damages may be used to enhance recovery of general damages."). See also id. at $\S 9: 13$.

33. Brown \& Williamson Tobacco Corp. v. Jacobson, 827 F.2d 1119, 1139 (7th Cir. 1987). 
$\$ 3$ million in presumed damages (reduced to $\$ 1$ million on appeal), without proof of economic loss resulting from the defamatory falsehood. In Dun \& Bradstreet, Inc. v. Greenmoss Builders, Inc. ${ }^{34}$ the U.S. Supreme Court upheld a $\$ 350,000$ award of presumed and punitive damages to plaintiff Greenmoss Builders, even though it had not proven actual reputational harm.

Special damages compensate the plaintiff for proven financial loss flowing directly from the reputational injury caused by the defamation. ${ }^{35}$ Special damages compensate the plaintiff for "the loss of something having economic or pecuniary value." ${ }^{36}$ Courts have allowed special damages for harm such as loss of business, ${ }^{37}$ loss of earnings, ${ }^{38}$ and loss of credit. ${ }^{39}$ Special damages must be pleaded with specificity and proven with reasonable certainty. ${ }^{40}$

34. Dun \& Bradstreet, Inc. v. Greenmoss Builders, Inc., 472 U.S. 749 (1985).

35. See, e.g., I SACK, supra note $3, \S 10.3 .2$ ("Special damages are damages awarded to compensate the plaintiff for actual pecuniary loss ... [which] comprising special damages must flow directly from the injury to reputation caused by the defamation." (citing Brown \& Williamson Tobacco Corp., 827 F.2d at 1138; Nunez v. A-T Fin. Info., Inc., 957 F. Supp. 438, 441 (S.D.N.Y. 1997))). See also Robertson v. McLoskey, 680 F. Supp. 414, 415-16 (D.D.C. 1988) (stating that recovery of special damages in a defamation lawsuit is permissible).

36. See I SACK, supra note $3, \S 10.3 .2$ (citing RESTATEMENT (SECOND) OF TORTS $\S$ 575 cmt. b (1977) (cited with approval in Liberman v. Gelstein, 605 N.E.2d 344, 347 (N.Y. 1992))).

37. See, e.g., Morasse v. Brochu, 25 N.E. 74, 76 (Mass. 1890) (holding that physician's loss of patients constitutes special damages); WDM Planning, Inc. v. United Credit Corp., 404 N.Y.S.2d 5 (N.Y. App. Div. 1978) (holding that complaint alleging loss of business due to defendant's defamatory statements relating to plaintiff's business practices "constitutes an allegation of special damages, sufficient ... to withstand a motion to dismiss the complaint").

38. See, e.g., Century Material Art Supply, Inc. v. Nat'l Ass'n of Prof'l Martial Artists, 129 Fed. App'x 421 (10th Cir. 2005) (awarding plaintiff lost earnings which resulted from defamation by defendants).

39. See, e.g., Dun \& Bradstreet, Inc., 472 U.S. at 783-84; Prettyman v. Shockley, 4 Del. (4 Harr.) 112 (1844); Redlich, supra note 30, at 1169 ("A defamation may also lead to a drop in a company's credit rating or other impairment in corporate access to the debt markets, similarly damaging a company's economic performance.").

40. See, e.g., Erick Bowman Co. v. Jensen Salsbury Labs., 17 F.2d 255, 261 (8th Cir. 1926).

It was therefore necessary for the plaintiff to allege either the loss of particular customers by name, or a general diminution in its business, and extrinsic facts showing that such special damages were the natural and direct result of the false publication. If the plaintiff desired to predicate its right to recover damages upon general loss of custom, it should have alleged facts showing an established business, 
Economists have advocated, and courts have accepted a decline in the stock price of a defamed corporation as an economic measure of its reputational harm. ${ }^{41}$ Dean Norman Redlich comments,

the amount of sales for a substantial period preceding the publication, the amount of sales subsequent to the publication, facts showing that such loss in sales were the natural and probable result of such publication....

Id. (cited with approval in Fowler v. Curtis Publ'g Co., 182 F.2d 377, 379 (D.C. Cir. 1950)); Robertson v. McLoskey, 680 F. Supp. 414, 416 (D.D.C. 1988) ("[S]pecific evidence demonstrating the financial harm resulting from the libel is required before compensation for economic harm can be awarded."). See also Jones v. W. \& S. Life Ins. Co., 91 F.3d 1032 (7th Cir. 1996); Christopher Lisa Policano, Inc. v. N. Am. Precis Syndicate, Inc., 514 N.Y.S.2d 239 (N.Y. App. Div. 1987); DAN B. DOBBS, THE LAW OF TORTS 1143 (2001) (describing "special harm" as "specifically identified pecuniary harm resulting from the slander"); FED. R. CIV. P. 9(g) ("If an item of special damage is claimed, it must be specifically stated.").

41. See, e.g., Sterling Sav. Ass'n v. Ryan, 751 F. Supp. 871, 877 (E.D. Wash. 1990) (finding that the plaintiff had "already suffered immeasurable injury in the form of damage to reputation and the accompanying loss of business. Strong evidence of this is the fact that the value of Sterling's common stock has dropped in recent months from $\$ 9.00$ per share to $\$ 4.00$ per share.”); Langdon v. Hillside Coal \& Iron Co., 41 F. 609 , 609 (C.C.S.D.N.Y. 1890) (stating that defamation of a corporation may lead to depreciation of the value of its shares); Diamond v. Oreamuno, 24 N.Y.2d 494, 499 (1969) (stating that corporate misconduct, such as insider trading, may injure a corporation's reputation for integrity and probity and undermine the value of its securities); Aswath Damodaran, INVESTMENT VALUATION 555 (2d ed. 2002) ("One of the benefits of having a well-known and respected brand name is that firms can charge higher prices for the same products, leading to higher profit margins and hence to higher price-sales ratios and firm value."); CHARLES J. FOMBRUN, REPUTATION 94-96 (1996) ("For public companies, changes in the market value of a firm provide a reasonable estimate of the anticipated losses to a company from attacks on its integrity and credibility; they also provide a gauge of how much of a company's reputational capital is put at risk from such events."); JULIE A. SCOTT-BAYFIELD, DEFAMATION: LAW AND PRACTICE 118 (1st ed. 1996) ("[ []f a plaintiff company can show that its share price has been affected by the alleged libel . . . that could form the basis of a claim for special damages."); Jacqueline A. Egr, Comment, Closing the Back Door on Damages: Extending the Actual Malice Standard to Publication-Related Damages Resulting from Newsgathering Torts, 49 U. KAN. L. REV. 693, 718 (stating that economic losses "such as reduced stock value and lower profits ... are directly related to the plaintiffs' loss of reputation ....'); Herzfeld, supra note 19, at 138 (“[T]njury to a corporation's business reputation may be indirect and of varying nature. It could include . . a decrease in the market value of the corporation's stock."); Lyrissa Barnett Lidsky, Silencing John Doe: Defamation \& Discourse in Cyberspace, 49 DUKE L.J. 855, 877 ("Corporate plaintiffs are at least partly motivated by the fear that negative statements on financial bulletin boards will drive down their stock price. The stock market trades on information, and negative information shifts stock prices very quickly." (citing WILLIAM A. KLEIN \& 


\section{OF CORPORATE \& FINANCIAL LAW}

"[o]f particular importance to a publicly held corporation is a defamation's impact upon financial markets. A defamation may lead to a dramatic drop in the market value of a company's stock. Moreover, since corporate transactions are often directly dependent on stock values, the consequential impact of a drop in share values can be enormous .... A A defamation may also lead to a drop in a company's credit rating or other impairment in corporate access to the debt markets, similarly damaging a company's economic performance." 42

The analysis in this Article establishes the legal validity of this approach.

\section{CORPORATE REPUTATION}

A tort remedy must match the substantive right at issue. ${ }^{43}$ The substantive right guarded by defamation law is the integrity of a plaintiff's reputation. ${ }^{44}$ Special damages for defamation must therefore be based on a financial measure of reputational harm. In order to quantify reputational harm, a concept of corporate reputation must be defined that is capable of valuation. ${ }^{45}$ This is the topic of this section.

Reputation is a complex and multidisciplinary concept. The academic literatures on reputation in fields such as economics, ${ }^{46}$

John C. COFFEe, Business ORganization and FinanCE: Legal and ECONOMiC PRINCIPLES 392 (1996))).

42. See Redlich, supra note 30 , at 1169.

43. See III DAN B. DobBS, LAW OF REMEdIES: DAMAGES - EQUITY - RESTITUTION 9 (2d ed. 1993).

44. See, e.g., David Rolph, Reputation, Celebrity and Defamation Law 19 (2008) (describing reputation as "the central interest directly protected by defamation law"); Themo v. New England Newspaper Publ'g Co., 27 N.E.2d 753, 755 (Mass. 1936) ("[The] right to freedom from defamation... concerns primarily one's reputation.").

45. See Robert C. Post, The Social Foundations of Defamation Law: Reputation and the Constitution, 74 CAL. L. REV. 691, 719-20 (1986) (stating that it is necessary, "if defamation law is to serve a coherent purpose, to define and articulate concepts of reputation that more narrowly define the specific forms of social apprehension to be legally protected").

46. See, e.g., PaUl Milgrom \& John Roberts, Economics, Organization \& MANAGEMENT 603 (1992) (defining reputation as "[t]he view formed of an individual or organization by another based on past experience, especially as a basis for forecasting future behavior"); Charles Fombrun \& Cees Van Riel, The Reputational Landscape, 1 CORP. REPUTATION REV. 5, 5-6 (1997). 
accounting, ${ }^{47}$ strategy ${ }^{48}$ marketing ${ }^{49}$ and sociology, ${ }^{50}$ tend to focus on reputation in the context of the respective disciplinary perspectives, but have not produced a unique and universally applicable definition of corporate reputation. ${ }^{51}$ Reputation scholars have nevertheless identified conceptual commonalities across disciplines. ${ }^{52}$ Professors Charles Fombrun and Cees Van Riel, for instance, synthesized an integrative

Economists view reputations as either traits or signals. Game theorists describe reputations as character traits that distinguish among 'types' of firms and can explain their strategic behavior. Signalling theorists call our attention to the informational content of reputations. Both acknowledge that reputations are actually perceptions of firms held by external observers.

Id.; J.E. Stiglitz, Imperfect Information in the Product Market, in HANDBOOK OF INDUSTRIAL ORGANIZATION ch. 13 (R. Schmalensee \& R.D. Willig eds., 1989).

47. See, e.g., Karl ERIK Sveiby, The NeW ORGanizational Wealth: Managing AND MEASURING KNOWLEDGE-BASED AsSETS (1997).

48. See, e.g., R.E. Caves \& M.E. Porter, From Entry Barriers to Mobility Barriers: Conjectural Decisions and Contrived Deterrence to New Competition, 91 Q. J. ECON. 421 (1977); Irene Devine \& Paul Halpern, Implicit Claims: The Role of Corporate Reputation in Value Creation, 4 CORP. REPUTATION REV. 42, 42 (2001) ("Reputation signals publics about how a firm's product quality, service, employment characteristics, strategies, and prospects compare to those of competing firms."); Keith Weigelt \& Colin Camerer, Reputation and Corporate Strategy: A Review of Recent Theory and Applications, 9 STRATEGiC MGMT. J. 443, 443-44 (1988).

While each player is assumed to know its own type, players are uncertain about the types of other players. Since a player's type influences preferences, and thus objectives, determining other players' types is an important strategic issue. Players gather data to form beliefs about the types rivals might be. If players observe past hisiory, and types are stable, one clue is the reputation of a player. Id.

49. See, e.g., Manto Gotsi \& Alan M. Wilson, Corporate Reputation: Seeking a Definition, 6 CORP. COMM. J. 24 (2001).

50. See, e.g., Fombrun \& Van Riel, supra note 46 (discussing economic, organizational, sociological, and accounting views of corporate reputation); Susan P. Shapiro, The Social Control of Impersonal Trust, 93 AM. J. Soc. 623 (1987).

51. See, e.g., Rosa Chun, Corporate Reputation: Meaning and Measurement, 7 INT. J. MGMT. REVS. 91, 92 (2005) ("Within the reputation paradigm, there is arguably no one source as yet which captures the entirety of the concept of reputation."); Gotsi \& Wilson, supra note 49, at 24 ("[D] espite the increasing number of studies published in the area, there is no unambiguous, generally accepted definition for the term corporate reputation" and "the value of being seen as 'a good company."').

52. See, e.g., Michael L. Barnett et al., Corporate Reputation: The Definitional Landscape, 9 CORP. REPUTATION REV. 26 (2006) (providing a literature survey of the concept of corporate reputation); Michael L. Barnett et al., Towards One Vision, One Voice: A Review Essay of the Third International Conference on Corporate Reputation, Image and Competitiveness, 3 CORP. REPUTATION REV. 101 (2000). 
definition of corporate reputation in terms of perceptions of stakeholders of the firm: "A corporate reputation is a collective representation of a firm's past actions and results that describes the firm's ability to deliver valued outcomes to multiple stakeholders. It gauges a firm's relative standing both internally with employees and externally with its stakeholders, in both its competitive and institutional environments."

The common law has not settled on a unique definition of reputation, ${ }^{54}$ in part because the diversity of legal contexts in which it is commonly encountered makes a universal definition impracticable. ${ }^{55}$ Professor Robert Post describes three concepts of reputation that have been most influential in defamation, namely reputation as property, as honor, and as dignity. ${ }^{56}$ Honor and dignity are appropriate characterizations of personal reputation, but not of corporate reputation. A corporation has no personality, and cannot experience human emotions such as pride or shame. ${ }^{57}$ Its reputational interest is purely

53. See Fombrun \& Van Riel, supra note 46, at 10 (stating "[a] corporate reputation is a collective representation of a firm's past actions and results that describes the firm's ability to deliver valued outcomes to multiple stakeholders").

54. See Post, supra note 45, at 692 ("Reputation . . . is a mysterious thing. The common law, as a rule, has 'not attempted to define reputation."' (citing Developments in Law-Defamation, 69 HARV. L. ReV. 875, 877 (1956))).

55. See, e.g., ROLPH, supra note 44 , at 1 ("[T]here has been insufficient detailed academic consideration of the concept of reputation in defamation law."); Post, supra note 45, at 719 ("[T]he field of reputation is vast and encompassing, virtually coextensive with society itself. It makes little sense in such a context to speak of defamation law as 'protecting reputation,' for such a task would be at once too enormous and too diffuse.").

56. See Post, supra note 45, at 693 (explaining that " $[t]$ hese three concepts are not the only possible concepts of reputation, but [that] they have had by far the most important impact on the development of the common law of defamation").

57. See, e.g., Nat'l Ref'g Co. v. Benzo Gas Motor Fuel Co., 20 F.2d 763, 766 (8th Cir. 1927).

[T] he legal principles constituting the law of libel are the same whether corporations or individuals are involved. But there are recognized distinctions between the application of those principles to individuals and their application to corporations, growing largely out of differences between natural and artificial persons. For example, a corporation is incapable of committing certain acts, especially some crimes, which an individual would be capable of committing; and again, a corporation has no merely personal reputation in the sense that an individual has.

Id.; Restatement (SECOND) OF TORTS $§ 561 \mathrm{cmt}$. d (1977); R. PhelPS ET Al., Libel: RIGHTS, RISKS, RESPONSIBILITIES 80 (rev. ed. 1978) ("[The business corporation] has no personality, no dignity that can be assailed, no feelings that can be touched. Since it cannot suffer physical pain, worry or distress, it cannot lie awake nights brooding about a defamatory article."); PROSSER ET AL., supra note 6, $\$ 111$, at 779 ("A corporation is 
economic. ${ }^{58}$ Companies with sound reputations enjoy economic benefits such as premium prices for their products, loyal patronage, and sound relations with labor, suppliers and customers. ${ }^{59}$ The value provided by these benefits is diminished when a company is defamed. ${ }^{60}$

The legal concept of corporate reputation most appropriate to the economic nature of the interest protected by defamation law is that of property. ${ }^{61}$ A consensus view has emerged in the common law, ${ }^{62}$

regarded as having no reputation in any personal sense ... [b]ut it has prestige and standing in the business in which it is engaged, and language which casts an aspersion upon its honesty, credit, efficiency or other business characteristic may be actionable."); SCOTT-BAYFIELD, supra note 41 , at 25 (The law recognizes that "[a] company, as well as an individual, has a reputation which can be damaged, and although it cannot be awarded damages for hurt feelings or distress, it can be awarded damages for injury to its goodwill."); Fetzer, supra note 18, at 53 n.95 ("A corporation, unlike an individual, 'has no character to be affected by a libel."" (citing Reporters' Ass'n of Am. v. Sun Printing \& Publ'g Ass'n, 79 N.E. 710,711 (N.Y. 1906))).

58. See, e.g., Martin Marietta Corp. v. Evening Star Newspaper Co., 417 F. Supp. 947, 955 (D.D.C. 1976) ("Although a corporation may maintain an action for libel, it has no personal reputation and may be libeled only by imputation about its financial soundness or business ethics." (citing Golden Palace, Inc. v. NBC, 386 F. Supp. 107, 109 (D.D.C. 1974))); Lewis v. Daily Tel. Ltd., [1964] A.C. 234, 262 (H.L) (“A company cannot be injured in its feelings, it can only be injured in its pocket. Its reputation can be injured by a libel but that injury must sound in money. The injury need not necessarily be confined to loss of income. Its goodwill may be injured."); Nessa E. Moll, In Search of the Corporate Private Figure: Defamation of the Corporation, 6 HoFSTRA L. REV. 339, 339 (1978); Redlich, supra note 30, at 1167 ("[A] publicly held corporation is not an emotional being; it exists essentially to economically benefit its shareholders.").

59. See, e.g., FoMBrUN, supra note 41 , at $72-73$ (1996) ("If being perceived by constituents as credible, reliable, trustworthy, and responsible is the hallmark of a good reputation, it pays off because well-regarded companies generally [(1)] command premium prices for their products, [(2)] pay lower prices for purchases, [(3)] entice top recruits to apply for positions, [(4)] experience greater loyalty from consumers and employees, [(5)] have more stable revenues, [(6)] face fewer risks of crisis, and [(7)] are given greater latitude to act by their constituents.").

60. See id. at 94-96 ("For public companies, changes in the market value of a firm provide a reasonable estimate of the anticipated losses to a company from attacks on its integrity and credibility; they also provide a gauge of how much of a company's reputational capital is put at risk from such events.").

61. See, e.g., Eric Barendt, What Is the Point of Libel Law?, 52 CURRENT LEGAL PROBLEMS 110, 115 (1999) ("The concept of reputation as property may explain . . . why corporations can sue to protect their good name, an entitlement which is much harder to justify if reputation is considered in terms of personal honour or dignity."); Herzfeld, supra note 19, at 140; Post, supra note 45, at 696 ("There are aspects of 
statutes, ${ }^{63}$ treatises, ${ }^{64}$ and academic commentary ${ }^{65}$ of corporate

modern defamation law that can be understood only by reference to the concept of reputation as property, as, for example, the fact that corporations and other inanimate entities can sue for defamation."); id. at 727 ("From the constitutional point of view, the concept of reputation as property is the least problematic of all justifications for defamation law.").

62. See, e.g., Food Lion, Inc. v. Capital Cities/ABC, Inc., 194 F.3d 505, 523 (4th Cir. 1999) (concluding that "Food Lion, in seeking compensation for matters such as loss of good will and lost sales, [was] claiming reputational damages from publication ...."); State Dep't of Transp. v. Cowan, 103 P.3d 1, 5 (Nev. 2004) ("While different jurisdictions vary slightly in their definitions of goodwill, the term generally is used to describe that component of value attributed to a business's reputation in the community, loyal customer base and ability to attract new customers.); Dugan v. Dugan, 457 A.2d 1, 6 (N.J. 1983) ("Though other elements may contribute to goodwill . . reputation is at the core."); In re the Marriage of Lukens, 558 P.2d 279, 281 (Wash. Ct. App. 1976) (finding that the value of the goodwill in a medical practice depended on factors such as the practitioner's reputation in the community for judgment, skill and knowledge); Holbrook v. Holbrook, 309 N.W.2d 343, 350 (Wis. Ct. App. 1981) (stating that a business's goodwill is essentially its reputation); Warnink v. Townend \& Sons (Hull) Ltd., [1979] 1 A.C. 731, 741 (H.L.) (defining goodwill as "the benefit and advantage of the good name, reputation and connection of a business . . . [and] the attractive force which brings in custom"); Allen Parkman, The Treatment of Professional Goodwill in Divorce Proceedings, 18 FAM. L. Q. 213, 216, 219 (1984) ("[P]rofessional goodwill is just another word for reputation," and "[a] number of courts, such as California, Washington, New Mexico, and New Jersey, have taken the position that 'reputation' is 'goodwill."' (citing Mueller v. Mueller, 301 P.2d 90 (Cal. App. 1956))).

63. See, e.g., CAL. CIV. Proc. CODE $\S 1263.510$ (b) (West 1982) (definition of goodwill acknowledges benefits accruing to a business from "reputation for dependability, skill or quality").

64. See, e.g., 38 AM. JUR. 2D Good Will § 1 ("Good will . . basically consists of the positive reputation that a particular business enjoys."); BLACK'S LAw DICTIONARY 763 (9th ed. 2009) (defining goodwill as “[a] business's reputation, patronage, and other intangible assets that are considered when appraising the business, esp. for purchase"); J. THOMAS MCCARTHY, MCCARTHY ON TRADEMARKS AND UNFAIR COMPETITION $\S$ 2:17 (4th ed. 2003) (stating that "the favorable consideration shown by the purchasing public to goods known to emanate from a particular source" establishes goodwill); 4-13 NiCHOLS ON EMINENT DOMAIN $\S 13.18$ ("Good will' in the legal sense has come to mean the advantage that a business has over competitors as a result of its name, location, and owner's reputation."); Morgan v. Perhamus, 36 Ohio St. 517, 522 (1881) (stating that "[i]n Lindley on Partnership, 842, the author, commenting on the meaning of the term good-will, says, that 'it is generally used to denote the benefit arising from connection and reputation ... “"); Robert W. Levis, Valuation of Businesses in Colorado Divorces, 32-JUN Colo. L., June 2003, at 73, 75 (citing AMERICAN INSTITUTE OF CERTIFIED PUBLIC ACCOUNTANTS ET AL., INTERNATIONAL GLOSSARY OF Business Valuation TERMS p. 5 (2001) (defining goodwill as "that intangible asset 
reputation as a core element of the constellation of intangible assets that collectively comprise a corporation's goodwill. The next section explores the legal, economic and accounting meanings of goodwill.

\section{GOODWILL}

An ongoing, functioning business is worth more than the sum of its parts. The residual value represents the goodwill of the business. ${ }^{66}$ The accounting definition of goodwill focuses on its measurement, while the economic view explains its existence and value. ${ }^{67}$ The analysis in this

arising as a result of name, reputation, customer loyalty, location, products, and similar factors not separately identified.")).

65. See, e.g., SCOTT-BAYFIELD, supra note 41 , at 25 (the law recognizes that "[a] company, as well as an individual, has a reputation which can be damaged, and although it cannot be awarded damages for hurt feelings or distress, it can be awarded damages for injury to its goodwill'); Mark D. Bloom et al., Reorganizing in a Fish Bowl: Public Access vs. Protecting Confidential Information, 73 AM. BANKR. L.J. 775, 776 (1999) (describing celebrity O.J. Simpson's reputation as "undoubtedly the most significant aspect of his business goodwill"); Parkman, supra note 62, at 219 ("[P]rofessional goodwill is just another word for reputation."); Post, supra note 45, at 693 ("The concept of reputation that is most easily available to contemporary observers is that of reputation in the marketplace. This concept of reputation can be understood as a form of intangible property akin to goodwill."); Oded Shenkar \& Ephraim YuchtmanYaar, Reputation, Image, Prestige, and Goodwill: An Interdisciplinary Approach to Organizational Standing, 50 HUM. ReL. 1361, 1361 (1997) ("Various terms are used to describe the relative standing of organizations. In sociology, prestige is the preferred term, in economics it is reputation, in marketing, image, and in accountancy and law, goodwill."); Randall B. Wilhite, The Effect of Goodwill in Determining the Value of a Business in a Divorce, 35 FAM. L. Q. 351, 352 (2001) ("A consistent thread running through the several different definitions of goodwill is the company's reputation. If the company's reputation gives it a competitive advantage over other businesses, the existence of goodwill is almost always present."); Carmen Valle Patel, Note, Treating Professional Goodwill as Marital Property in Equitable Distribution States, 58 N.Y.U. L. REV. 554, 554 (1983) ("Goodwill, broadly defined, is the intangible value of a business derived from its reputation and established clientele.").

66. See, e.g., James H. Snelson, Financial Statements, 12 AM. BANKR. INST. J., Dec./Jan. 1994, at 13 (stating that to accountants, goodwill is an acknowledgement that an operating, ongoing business is "greater than the sum of its parts"); Andrew F. Halaby, Comment, Treatment of Goodwill by the Seller Under I.R.C. Section 197, 43 KAN. L. REV. 903, 905 (1995) ("[A]n operating business with an existing customer base is worth more than the mere aggregate value of its tangible and identifiable intangible assets because the purchaser may expect customers of the purchased business to continue their patronage.").

67. Parkman, supra note 62, at 213 ("Generally, accounting has been interested in 
section shows that the modern legal view of goodwill has adopted the accounting and economic meanings.

\section{Accounting View of Goodwill}

Accountants define goodwill as a constellation of intangible assets which give rise to supranormal earnings and excess value. ${ }^{68}$ Supranormal earnings is defined as earnings in excess of a normal return on the tangible and identifiable intangible assets of a business. ${ }^{69}$ Accountants measure the value of goodwill as the difference between the total value of a company and the aggregate value of its tangible and identifiable intangible assets. ${ }^{70}$ This amount equals the present value of

measuring [the] value [of goodwill], while economics has been interested in explaining its basis.").

68. See GlenN A. Welsch ET Al., InTERmediate ACCOUNTING 438 (6th ed. 1982) (defining goodwill as "an economic advantage which exists when the total value of a business is more than the value of all its identifiable net assets. This economic advantage arises because the expected earnings of the business exceed the level of earnings on only its identifiable net assets ...."); Keith W. Chauvin \& Mark Hirschey, Goodwill, Profitability, and the Market Value of the Firm, 13 J. ACCT. \& PUB. POL'Y 159,162 (1994) ("[A]ccounting goodwill is described as among those intangible assets and conditions which give rise to above-average strength in terms of technical skill and knowledge, management, marketing research and promotion which cannot be separately identified and valued. Alternatively, goodwill represents the value derived from a firm's ability to generate above-normal earnings.").

69. See Parkman, supra note 62, at 214. See also BLACK's LAW DictionaRY 763 (9th ed. 2009) (defining goodwill as "the ability to earn income in excess of the income that would be expected from the business viewed as a mere collection of assets"); JAY M. SMITH ET AL., INTERMEDIATE ACCOUNTING 437 (12th ed. 1995) (defining goodwill as "the intangible resources, factors, and conditions that allow a business to earn abovenormal income with the identifiable assets employed in the business"); Wilhite, supra note 65 , at 353 (defining goodwill as "the ability to earn a rate of return in excess of a normal rate of return on the net assets of the business.").

70. See, e.g., Rev. Rul. 59-60, 1959-1 C.B. 237, 241; BARUCH LEV, INTANGIBLES: MANAGEMENT, MEASUREMENT, AND REPORTING 137 (2001) (defining goodwill as "the excess of the cost of an acquired company over the sum of identifiable net assets"); WELSCH, supra note 68, at 438 (defining goodwill as "an economic advantage which exists when the total value of a business is more than the value of all its identifiable net assets"); Larry E. Ribstein, A Theoretical Analysis of Professional Partnership Goodwill, 70 NEB. L. REV. 38, 40 (1991) (stating that accountants define goodwill as "“excess' value that cannot be attributed to specific tangible and intangible assets ... [t] his value can be determined by assigning values to specific assets and subtracting these from the actual value of the firm, perhaps based on capitalizing the firm's earnings"). 
the supranormal earnings stream generated by the company's goodwill. $^{71}$ The Coca Cola Company is a prime example of a corporation that has been able to capitalize on its reputation and brand name to realize substantial goodwill value and excess earnings, evidenced by a higher profit margin than a typical generic competitor. ${ }^{72}$

The term "goodwill" does not refer to specific assets. Rather, it is "a catch-all residual category, a label given to the going concern value of assets . . . over and above those that can be kicked or counted, or weighed, or valued with some precision." 73 Goodwill includes items such as reputation, a favorable location and technological efficiency. ${ }^{74}$

71. See WelSCH ET AL., supra note 68, at 438 (stating that the "economic advantage arises because the expected earnings of the business exceed the level of earnings on only its identifiable net assets . . "); Parkman, supra note 62, at 214 ("The Capitalized value of the supranormal profits stream is the asset value of goodwill.").

72. See, e.g., DAMODARAN, supra note 41 , at 555 ("One of the benefits of having a well-known and respected brand name is that firms can charge higher prices for the same products, leading to higher profit margins and hence to higher price-sales ratios and firm value. The larger the price premium that a firm can charge, the greater is the value of the brand name.").

73. Margaret Blair \& Steven Wallman, Growing Intangibles Reporting Discrepancy, in INTANGIBle AsSets: Values, MEASURES, AND RISKS 455 (John R.M. Hand \& Baruch Lev eds., 2003). See also Robert F. Reilly, SFAS Nos. 141 and 142 Implications for Goodwill Acquired by M\&A, 25-1 AM. BANKR. INST. J., Feb. 2006, at $48,49-50$ (explaining that the assets of a business typically consist of financial assets such as (1) cash and marketable securities; (2) tangible or physical assets, such as property, plant and equipment; (3) intangible assets that can be valued discretely, such as patents, trademarks and proprietary software; and (4) goodwill); Note, An Inquiry into the Nature of Goodwill, 53 COLUM. L. REV. 660, 678 (1953) (goodwill does not include intangible assets which are specifically enumerated, such as leases, licences, patents, copyrights, trademarks, trade secrets, and subscription lists).

74. See, e.g., H.A. FinNey \& Herbert E. Miller, Principles of ACCOUNTING 216-17 (6th ed. 1963) ("[S]ince good will is dependent upon earnings, and since many things other than customer satisfaction contribute to earnings, there are many sources of goodwill. Some of these sources are: location; manufacturing efficiency; satisfactory relations between the employees and the management . . . ; adequate sources of capital and a credit standing ... ; advertising; monopolistic privileges; and, in general, good business management."); Grace Ganz Blumberg, Identifying and Valuing Goodwill at Divorce, 56 LAW \& CONTEMP. ProBs. 217, 221-22 (1993) ("In addition to reputation and continuing patronage, goodwill may include, inter alia, strategic location, effective advertising, the value of a skilled, trained, efficient work force, assemblage of property, plant, and equipment in a productive unit, and systems, controls, and methods developed as part of the operation."); Chauvin \& Hirschey, supra note 68, at 165 ("Other pecuniary sources of goodwill might include special access to government subsidies, market power derived from licenses or other barriers to entry, and unexpected 


\section{OF CORPORATE \& FINANCIAL LAW}

Because it is so subjective, goodwill does not usually appear on a firm's balance sheet. ${ }^{75}$ It is nevertheless a significant and valuable corporate asset. By one estimate, goodwill comprises at least 80 percent of the market capitalization of firms listed on the S\&P $500 .^{76}$

Accountants usually recognize goodwill on the balance sheet only when the firm is acquired. ${ }^{77}$ Professors Margaret Blair and Steven Wallman explain,

“[w] hen company A acquires company B, A adds B's net assets

benefits derived from contracts based on terms which later prove to be highly favorable."); Note, An Inquiry into the Nature of Goodwill, 53 COLUM. L. REV. 660, 678-79 (1953) (" $[\mathrm{G}]$ oodwill is meant to embrace a residue, to include all those advantages possessed by a firm which cannot be subjected to a definitive valuation .... As the embodiment of unassignable advantages, it includes all those factors of economic significance which, in a particular enterprise, have not been specifically accounted for.").

75. See HandBooK of AcCounting AND Auditing 23-33 (Robert S. Kay \& D. Gerald Searfoss eds., 1988); Chauvin \& Hirschey, supra note 68, at 160.

In terms of intangibles, the accounting profession restricts valuation and asset recognition to items which are clearly identifiable such as copyrights, licensing agreements, patents, trademarks, trade names, and so on. Other intangible assets, such as an honorable business reputation, good customer relations, unique market position, a well-trained work force, or the value of brand names have generally been deemed too ethereal to warrant recognition.

Id.; Haim Falk \& L.A. Gordon, Imperfect Markets and the Nature of Goodwill, $4 \mathrm{~J}$. BUS. FIN. \& ACCOUNTING 443, 443 (1977) ("Many have argued that the nature of goodwill is such that it is neither 'fowl nor fish' and accordingly should not be included on financial statements."); Ribstein, supra note 70, at 40 ("Largely because of its highly subjective nature, goodwill is not accounted for on a company's balance sheet unless the company has established its value by purchasing it." (citing SIDNEY DAVIDSON \& ROMAN L. WeIL, HANDBOOK OF MODERN ACCOUNTING 21-15 (2d ed. 1977))). But see Reilly, supra note 73 , at 49 ("There are a few instances when internally created goodwill is recorded on a company's financial statements, such as under the push-down accounting rules related to corporate reorganization. But the instances in which a company's internally developed goodwill (as opposed to its purchased goodwill) is recognized for accounting purposes are rare.").

76. See George P. Roach, A Business Appraiser's Model for Separating Professional and Personal Goodwill, 18 FAIR\$HARE No. 8, Aug. 1998, at 13.

77. See, e.g., Dugan v. Dugan, 457 A.2d 1, 5-6 (N.J. 1983) ("Accountants will usually not reflect goodwill on a balance sheet until after a business has been sold and then state goodwill in terms of the excess paid for the net assets over book value."); DAVIDSON \& WEIL, supra note 75, at 21-15; BARRY ELLIOTT \& JAMIE ELLIOTT, FINANCIAL ACCOUNTING AND REPORTING 208 (4th ed. 2000) ("Goodwill arising on the acquisition of a subsidiary or business is the difference between the consideration paid and the fair value of the assets and liabilities acquired."). 
(assets minus liabilities) to the net assets on its own balance sheet. If $\mathrm{B}$ has $\$ 500$ million worth of property, plant and equipment, financial and other identifiable assets and zero liabilities on its books, those assets will be added to the books of $\mathrm{A}$. But suppose that $\mathrm{A}$ has paid $\$ 750$ million for $B$. How does it account for the additional $\$ 250$ million that are not reflected in B's book value? If possible, A would first 'write up', or assign a higher value - based on appraisals to the acquired hard assets. Then it would assign a value to any specific intangibles that could be identified and valued. Finally, A would add the remaining amount (say $\$ 200$ million) to its books as goodwill.",78

\section{Economic View of Goodwill}

Accountants define goodwill in terms of supranormal earnings and the excess value they represent. Economists explain the excess earnings and value in terms of productive synergies between goodwill and the firm's other assets. A synergy is created when two or more elements combine to produce a result that is more valuable than the individual elements acting alone. ${ }^{79}$ Technological synergies, for instance, allow the combined capacity of two plants to produce a single product more efficiently than either plant by itself. The resulting cost savings are known as economies of scale. ${ }^{80}$

Goodwill combines with the firm's tangible and separately identifiable intangible assets to create synergies that increase the value of the firm beyond the value of these assets individually. A corporation relies on its reputation, for instance, to charge premium prices, ${ }^{81}$ to

78. Blair \& Wallman, supra note 73. See also DAMODARAN, supra note 41, at 33.

79. See, e.g., The AMERICAN HERITAGE Dictionary OF THE ENGLish LaNGUAGE 1821 (3d ed. 1996) (defining synergy as " $[\mathrm{t}]$ the interaction of two or more agents or forces so that their combined effect is greater than the sum of their individual effects"); Wilhite, supra note 65 , at 351 (stating that "a synergy develops when a number of elements come together, and the result of the union is that the collective output exceeds a yield that could have been rendered by the same elements acting alone"). See also Fred WaitzKin, Mortal Games the TuRbulent Genius of GarRy Kasparov 108 (1993) (Chess world champion, Garry Kasparov, reflecting upon his 1983 match against Lajos Portisch, describes a strategic synergy: "A knight away from the action is worth less than a knight poised to attack. When pieces are working in harmony, they are worth more than the same pieces in disunity.").

80. See MILGROM \& ROBERTS, supra note 46, at 598.

81. See, e.g., Franklin Allen, Reputation and Product Quality, 15 RaND. J. ECON. 311 (1984); Benjamin Klein \& Keith B. Leffler, The Role of Market Forces in Assuring Contractual Performance, 89 J. POL. ECON. 615 (1981) (theorizing that companies 


\section{OF CORPORATE \& FINANCIAL LAW}

obtain credit, ${ }^{82}$ customers ${ }^{83}$ and business partners; ${ }^{84}$ and to reduce the mobility of industry rivals, ${ }^{85}$ all of which contribute to profit and value. ${ }^{86}$

invest in brand names as an implicit guarantee of the quality of their products, for which consumers are willing to pay a premium: Firms signal their commitment to quality by investing in a brand name. Consumers are willing to pay high prices for products bearing the quality name. If the firm fails to maintain consistent quality, consumers abandon its product and the company loses its investment in the brand name.); Paul Milgrom \& John Roberts, Relying on the Information of Interested Parties, 17 RAND. J. ECON. 18 (1986) (positive reputation allows firm to charge premium prices); Chandrakanth Seethamraju, The Value Relevance of Trademarks, in INTANGIBLE ASSETS: VAlUeS, MEASURES, RISKS 233-34 (John Hand \& Baruch Lev eds., 2003) [hereinafter INTANGIBLE ASSETS] ("“One of the most obvious economic effects of a trademark is that it might permit the owner to charge more than others for a product or service that is very similar to others in the market place. This is caused by enhanced market demand for the subject product or service. If this enhanced market demand for the product or service is brought about by the magnetism of the trademark, then the income stream represented by the premium price can be attributed to this asset." ); Carl Shapiro, Premiums for High Quality Products as Returns to Reputations, 98 Q. J. ECON. 659 (1983).

82. See, e.g., Randolph P. Beatty \& Jay R. Ritter, Investment Banking, Reputation, and the Underpricing of Initial Public Offerings, 15 J. FIN. ECON. 213, 213-32 (1986) (positive reputation enhances firm's access to capital markets).

83. See, e.g., Mary E. Barth et al., Brand Values and Capital Market Valuation, in INTANGIBLE ASSETS, supra note 81, at 154 (stating that "a distinctive name" creates "a willingness to pay either higher than otherwise average prices or make higher than otherwise purchase frequency"); Stephen L. Carter, Comment, The Trouble with Trademark, 99 YALE L.J. 759, 763 (1990) (“[T]he more goodwill behind [a trademark], and the larger the number of consumers who attach a positive association to it, the better off the firm, which will make more sales at a higher price." (citing William Landes \& Richard Posner, Trademark Law: An Economic Perspective, 30 J. LAW \& ECON. 265, $277-79$ (1987))); William P. Rogerson, Reputation and Product Quality, 14 BELL. J. ECON. 508 (1983) (showing that a reputation for quality increases the likelihood of retaining customers and obtaining positive word-of-mouth advertising).

84. See, e.g., Shenkar \& Yuchtman-Yaar, supra note 65, at 1361 (stating that favorable reputation is crucial in obtaining partners in joint ventures).

85. See, e.g., Caves \& Porter, supra note 48, at 247, 251-53, 258; Robert Wilson, Reputations in Games and Markets, in GAMe Theoretic Models of Bargaining (Alvin E. Roth ed., 1985).

86. See, e.g., DAMODARAN, supra note 41 , at 555 ("One of the benefits of having a well-known and respected brand name is that firms can charge higher prices for the same products, leading to higher profit margins and hence to higher price-sales ratios and firm value. The larger the price premium that a firm can charge, the greater is the value of the brand name."); Chauvin \& Hirschey, supra note 68, at 177 ("[F]irms with a high-quality reputation reduce customer search costs, and often enjoy rapid revenue growth and/or high profit margins."); id. at 162-63 (literature review of firm 
The present value of the incremental revenue produced by these synergies represents the value of the corporation's goodwill. ${ }^{87}$

Empirical studies confirm the value-relevance of a positive reputation. Professors Mary Barth et al. for instance, conducted an empirical study examining the association between the brand value of a firm and its stock price. ${ }^{88}$ Barth et al. conclude that "brand value

characteristics which contribute to goodwill); Herzfeld, supra note 19, at 140 ("A corporation relies on its business reputation (as well as other things) to secure employees, customers, creditors and business partners. The ultimate product of this trading activity is the achievement of the corporation's objects, most often the making of profit.").

87. See, e.g., Reg S. Gynther, Some "Conceptualizing" on Goodwill, 44 ACCOUNTING REV. 247, 248 (1969) ("Goodwill would be the net present value of those assets that it has not been possible to list and value separately . . ."); Parkman, supra note 62 , at 214 ("The [c]apitalized value of the supranormal profits stream is the asset value of goodwill."). The excess earnings definition of goodwill, and its relation to excess value is illustrated by the following example provided by Professor Alan Zipp.

[C]onsider a business which invests $\$ 100,000$ in a single machine. If the alternative to purchase would be to rent this machine at a cost of $\$ 10,000$ per year, it is logical to assume that the first $\$ 10,000$ of earnings from the business are related to the investment in the machine rather than from the operations of the business. In this regard, the business could have received $\$ 10,000$ as rental income by leasing the equipment to another company. Therefore, if the net earnings of the business were $\$ 15,000$, the reasonable return on the cost of assets invested would be $\$ 10,000$, and the excess earnings of $\$ 5,000$ would represent the profitability of the business from operations [excess return]. It is this $\$ 5,000$ which represents the earnings from the intangible assets of the busines such as assembling assets, being in a good location, having a fine reputation, having satisfied customers, and providing a valuable service. The group of intangible assets which contribute to this excess $\$ 5,000$ of earnings are collectively referred to as goodwill and the value of goodwill is the substantive element of business valuation.

Alan S. Zipp, Divorce Valuation of Business Interests: A Capitalization of Earnings Approach, 23 FAM. L. Q. 89, 101 (1989).

88. Mary E. Barth et al., Brand Values and Capital Market Valuation, 3 ReV. ACCOUNTING STUD. 41 (1998). The brand name or trademark of a firm is closely related to its reputation and goodwill. See, e.g., Carter, supra note 83, at 762 (stating that a trademark "serves no other function and enjoys no legal existence independent of the goodwill that it symbolizes. Without goodwill, marks have no meaning ...."); id. at n.5 (stating "the value of [a] trademark is proportional to the goodwill that it represents"); William M. Landes \& Richard A. Posner, Trademark Law: An Economic Perspective, 30 J.L. \& ECON. 265, 270 ("The value of a trademark is the saving in search costs made possible by the information or reputation that the trademark conveys or embodies about the brand (or firm that produces the brand)."); S. REP. No. 79-1333, at 6 (1946), reprinted in 1946 U.S.C.C.A.N. 1274, 1277 (stating that "the protection of trade-marks is merely protection to goodwill"). 


\section{OF CORPORATE \& FINANCIAL LAW}

estimates capture information that is relevant to investors and are sufficiently reliable to be reflected in share prices and returns." authors also find that annual changes in brand values are correlated with stock returns, controlling for factors such as net income. ${ }^{90}$ Other economic studies on the value-relevance of reputation report similar results. ${ }^{91}$

A positive reputation adds value, but the converse is also true. Empirical studies show that reputational harm may impair goodwill. Studies report evidence of reputational penalties imposed by the stock market on firms accused of misconduct, or whose reputations were tainted in other ways. Professors Karpoff, Lee and Martin, for instance, examined the penalties imposed on firms that were targeted by SEC enforcement actions for financial fraud during the period $1978-2002 .{ }^{92}$ Although civil settlements and penalties imposed on these firms through the legal system were significant, the authors report that reputational penalties imposed by the stock market were much larger. The authors define a "reputational penalty" as the present value of losses due to lower future sales and higher contracting and financing costs. ${ }^{93}$ They

89. Barth et al., supra note 88 , at 42 .

90. Id.

91. See, e.g., Peter Antunovich \& David S. Laster, Abstract, Do Investors Mistake a Good Company for a Good Investment? (Fed. Res. Bank of N.Y. Staff Reports No. 60,1998 ) (concluding that a positive corporate reputation adds value to the firm, based on empirical evidence that "[a] portfolio of firms in the top decile [of Fortune's reputation ranking] earns an abnormal return of 3.2 percent in the year after the survey is published and 8.3 percent over [the following] three years"); Peter W. Roberts \& Grahame R. Dowling, Corporate Reputation and Sustained Superior Financial Performance, 23 STRATEGY MGMT. J. 1077, 1090 (2002) (statistical studies suggesting that superior-performing firms are more likely to sustain their performance if they also possess good reputations); Alvin E. Roth \& Francoise Schoumaker, Expectations and Reputations in Bargaining: An Experimental Study, 73 AM. ECON. REV. 362 (1983) (experimental study reporting that players' reputations, as evidenced by past behavior, affected bargaining outcomes); Carol Simon \& Mary Sullivan, The Measurement and Determinants of Brand Equity: A Financial Approach, 12 MKTG. SCI. 28, 48-52 (1993) (finding that firms with well-known brand names have high estimates of brand equity).

92. Jonathan M. Karpoff et al., The Cost to Firms of Cooking the Books, 43 J. Fin. \& QUANT. ANALYSIS 581 (2008).

93. See id. at 581. See also Joseph K. Tanimura \& Eric W. Wehrly, The Market Value and Reputational Effects from Lost Confidential Information (Working Paper Series 2009), available at http://ssm.com/abstract=1083891 ("A firm will incur a reputational penalty if the total costs of the breach-as measured by the market value loss in the company's shares-exceed the direct costs of the breach."). 
estimate the reputational penalty imposed on firms in their sample as more than 7.5 times the sum of all penalties imposed through the legal and regulatory system. ${ }^{94}$

Karpoff et al. explain the reputational effect as follows:

"[F]or each dollar that a firm misleadingly inflates its market value when its books are cooked, on average, it loses this dollar when its misconduct is revealed, plus an additional $\$ 3.07$. Of this additional loss, $\$ 0.36$ is due to expected legal penalties and $\$ 2.71$ is due to lost reputation. In firms that survive the enforcement process as independent entities, lost reputation is even greater at $\$ 3.83$ per dollar of artificially inflated value." 95

The study concludes that the stock market imposes substantial reputational penalties for accounting fraud. ${ }^{96}$

Empirical studies report evidence of reputational losses for various types of corporate misconduct, including false advertising, ${ }^{97}$ product recalls, ${ }^{98}$ air safety disasters, ${ }^{99}$ frauds of private parties, ${ }^{100}$ investigations of IPO underwriters, ${ }^{101}$ product tampering, ${ }^{102}$ and defense procurement

94. Karpoff et al., supra note 92, at 581.

95. Id.

96. Id.

97. See, e.g., Sam Peltzman, The Effects of FTC Advertising Regulation, 24 J.L. \& ECON. 403, 410-11 (1981).

98. See, e.g., Gregg Jarrell \& Sam Peltzman, The Impact of Product Recalls on the Wealth of Sellers, 93 J. PoL. ECON. 512 (1985); Mark L. Mitchell, The Impact of External Parties on Brand-Name Capital: The 1982 Tylenol Poisonings and Subsequent Cases, 27 ECON. INQUIRY 601, 616-17 (1989).

99. See, e.g., Andrew Chalk, Market Forces and Airline Safety: The Case of the $D C-10,24$ ECON. INQUIRY 43, 58 (1986); Mark L. Mitchell \& Michael T. Maloney, Crisis in the Cockpit? The Role of Market Forces in Promoting Air Travel Safety, 32 J.L. \& ECON. 329, 329-30 (1989) (reporting a statistically significant negative abnormal stock return following crashes due to pilot error, but no significant stock market reaction following crashes where the carrier was not at fault).

100. See, e.g., Cindy R. Alexander, On the Nature of the Reputational Penalty for Corporate Crime: Evidence, 42 J.L. \& ECON. 489, 489 (1999); Jonathan M. Karpoff \& John R. Lott, Jr., The Reputational Penalty Firms Bear from Committing Criminal Fraud, 36 J.L. \& ECON. 757, 758-59 (1993); Deborah L. Murphy et al., Understanding the Penalties Associated with Corporate Misconduct: An Empirical Examination of Earnings and Risk, 44 J. FIN. \& QUANT. ANALYSIS 55, 82-83 (2009).

101. See, e.g., Randolph P. Beatty et al., The Indirect Economic Penalties in SEC Investigations of Underwriters, 50 J. FIN. ECON. 151 (1998).

102. See, e.g., Mitchell \& Maloney, supra note 99, at 601-18 (reporting a decline in the value of the brand name of Johnson \& Johnson following recall of its Tylenol 
fraud. $^{103}$

\section{Legal View of Goodwill}

The common law has often struggled to understand and define goodwill. ${ }^{104}$ Courts and commentators captured essential elements of goodwill, but their definitions were often inadequate. The legal definition of goodwill has evolved over time, and the modern view has converged towards the accounting and economic meanings. Although modern courts tend to emphasize different aspects of goodwill in different legal contexts, their diverse viewpoints are generally substantively consistent. ${ }^{105}$ The occasional emergence of definitions contradicting the accounting and economic meanings has been attributed to "economic ignorance of courts and legal commentators," rather than a

capsules after serious product tampering); Thomas D. Dowdell et al., The Tylenol Incident, Ensuing Regulation, and Stock Prices, 27 J. FIN. \& QUANT. ANALYSIS 283 (1992) (finding similar results).

103. See, e.g., Jonathan M. Karpoff et al., Defense Procurement Fraud, Penalties, and Contractor Influence, 107 J. POL. ECON. 809, 814 (1999).

104. See, e.g., Agric. Serv. Ass'n, Inc. v. Ferry-Morse Seed Co., Inc., 551 F.2d 1057,1071 (6th Cir. 1977) ("[d]efining that which constitutes 'goodwill' is not easy"); Douthart v. Logan, 86 Ill. App. 294, 309 (Ill. App. Ct. 1899) ("The term goodwill can hardly be said to have any precise signification."); JOHN B. CANNING, THE ECONOMICS OF ACCOUNTANCY 38 (1929) ("Accountants, writers on accounting, economists, engineers, and the courts, have all tried their hands at defining goodwill, at discussing its nature, and at proposing means of valuing it. The most striking characteristic of this immense amount of writing is the number and variety of disagreements reached."); Kelly M. Haggar, Comment, A Catalyst in the Cotton: The Proper Allocation of the "Goodwill" of Closely Held Businesses and Professional Practices in Dissolution of Marriages, 65 LA. L. REV. 1191, 1211-12 (2005) (quoting Zipp, supra note 87, at 95 (" $[\mathrm{G}]$ oodwill is a mysterious possession, elud[ing] precise definition, ... [and although all] experts agree it exists, few experts agree on exactly what it is ... . [Many] have tried [to define and value it] but [t]he most striking characteristic of this immense amount of writing is the number and variety of disagreements reached.")); Ribstein, supra note 70, at 39 ("The existence and ownership of the 'goodwill' of professional partnerships is one of the most muddled subjects in partnership law. Courts employ different definitions of goodwill and reach disparate results."); id. at 51 ("Analysis ... is complicated by the fact that the courts often conclude that goodwill exists without precisely defining or attempting to value it.").

105. See, e.g., Andrew F. Halaby, Comment, Treatment of Goodwill by the Seller Under I.R.C. Section 197, 43 U. KAN. L. REv. 903, 904 (1995) (stating that common law definitions of goodwill differ "in flavor if not substance"). 
fundamental disconnect between law and economics. ${ }^{106}$

\section{$\underline{\text { Early View }}$}

The earliest legal definition of goodwill appeared in Cruttwell $v$. Lye, ${ }^{107}$ an English case from 1810. Cruttwell defined goodwill simply as "the probability that the old customers will resort to the old place." 108 Commentators and courts have generally viewed this definition as narrow and incomplete. ${ }^{109}$ Its exclusive focus on favorable customer relations ignores other synergies, such as those arising from economies of scale and favorable relations with suppliers and creditors. ${ }^{110}$ Also, significant custom by itself does not necessarily result in the sustained profitability necessary to establish the supranormal returns and value that characterize goodwill. ${ }^{11}$ In Christian v. Douglass, ${ }^{112}$ the court

106. Ribstein, supra note 70 , at 43 ("The legal definition of goodwill may differ from both the accounting and economic meanings. To some extent this seems attributable simply to the economic ignorance of courts and legal commentators."); see also Parkman, supra note 62, at 216 ("The confusion in the cases is based on the courts not focusing more closely on a clear definition of goodwill .... If the courts say there is goodwill in a sole practice, when there is none from an accounting or economic perspective, a problem of evaluation is created.").

107. Cruttwell v. Lye, (1810) 34 Eng. Rep. 129 (Ch.).

108. Id. at 134 .

109. See, e.g., Douthart v. Logan, 86 Ill. App. 294 (1899) (quoting Trego v. Hunt, [1896] A.C. 7, 17 ("If the language of Lord Eldon [in Cruttwell] is to be taken as a definition of good will of general application, I think it is far too narrow, and I am not satisfied that it was intended by Lord Eldon as an exhaustive defintion. Good will must mean every advantage-every positive advantage . . . that has been acquired by the old firm in carrying on its business ....")); Spayd v. Turner, 482 N.E.2d 1232, 1236 (Ohio 1985) ("A much narrower definition [of goodwill] has been stated as the probability that the old customers will resort to the old place.").

110. See, e.g., Ribstein, supra note 70, at 43.

111. See Red Wing Malting Co. v. Willcuts, 15 F.2d 626, 632 (8th Cir. 1926) (the value of goodwill "depends on earnings of a certain amount being maintained"); Wilhite, supra note 65 , at 352 n.6.

The expectation of continued public patronage does not always lead to a finding of excess value because, even a business with substantial repetitive trade and fierce customer loyalty may not have goodwill if the company's customers will not pay market rates for goods or services. Though these customers are very loyal, the business may actually be losing money (or making modest profits that are incongruent with the company's level of sales.

Id. (citing Jerald H. Udinsky, Goodwill Depreciation: A New Method for Valuing Professional Practices in a Marital Dissolution, 8 COMM. PROP. J. 307, 309 (1983)).

112. Churton v. Douglas, (1859) 174 Johns. 385 (Ch.). 


\section{OF CORPORATE \& FINANCIAL LAW}

acknowledged the limitations of Crutwell, and articulated a more expansive view of goodwill, as "every positive advantage acquired, arising out of the business of the old firm, whether connected with the premises where it was carried on, with the name of the late firm, or with any other matter carrying with it the benefit of the business of the old firm." 113

A (now-classic) definition of goodwill subsequently appeared in 1841 , in a treatise on partnership written by Justice Joseph Story. ${ }^{114}$ Justice Story defines goodwill as:

[An] advantage of benefit which is acquired by an establishment, beyond the mere value of the capital, stock, funds or property employed therein, in consequence of the general public patronage and encouragement which it receives from constant or habitual customers, on account of its local position, or common celebrity, or reputation for skill or affluence, or punctuality, or from other accidental circumstances or necessities, or even from ancient partialities or prejudices. ${ }^{115}$

This definition resembles elements of the modern accounting view, and is still widely cited in the common law. ${ }^{116}$

A third classic definition of goodwill was articulated by Judge Cardozo in In re Brown, ${ }^{117}$ a case that challenged the method by which the surviving partners of a brokerage firm accounted for its goodwill. Judge Cardozo focused on the role of location and customer loyalty in the valuation of goodwill, observing that "[m]en will pay for any privilege that gives a reasonable expectancy of preference in the race of competition .... Such expectancy may come from succession in place or name or otherwise to a business that has won the favor of its

113. Id. at 391 .

114. JOSEPH STORY, COMMENTARIES ON THE LAW OF PARTNERSHIP AS A BRANCH OF COMMERCIAL AND MARITIME JURISPRUDENCE WITH OCCASIONAL ILLUSTRATIONS FROM THE CIVIL AND FOREIGN LAW $\S 99$ (Boston, Little, Brown \& Co., 7th ed. 1881).

115. Id. at 157.

116. See, e.g., In re Marriage of McTiernan \& Dubrow, 133 Cal. App. 4th 1090, 1097 (Cal. Ct. App. 2005); Dantonio v. Fontana, 636 So. 2d 218, 225 (La. 1994) (establishing that there is more to goodwill than its material possessions and attributes); Dugan v. Dugan, 457 A.2d 1, 4 (N.J. 1983) (explaining that a significant element in fixing an attorney's goodwill is that when he sells his law practice a restrictive covenant protecting goodwill is unavailable); Taormina v. Culicchia, 355 S.W.2d 569, 573 (Tex. Civ. App. 1962).

117. In re Brown, 150 N.E. 581 (N.Y. 1926). 
customers. It is then known as good will."118

\section{Modern View}

The legal definition of goodwill has evolved from its narrow origins and converged towards its accounting and economic meanings. ${ }^{119}$

\section{Law has Adnpted Accounting Definition and Measurement}

The modern accounting view of goodwill as a constellation of intangible assets which generate supranormal earnings and excess value, has been adopted by the common law, statutory law, treatises and academic commentators, in diverse legal disciplines. ${ }^{120}$ The California

\section{Id. at 582 .}

119. See, e.g., Fine v. Lawless, 201 S.W. 160, 165-66 (Tenn. 1917) (noting the evolving legal view of goodwill: "The doctrine of 'good will' has proven to be so salutary in effecting just results that it has been constantly expanding, with the result that the definition of the word itself has been broadened as the doctrine has developed."); Haggar, supra note 104, at 1212.

A leading indicator of the sometimes very subtle but still profound shifting in meaning of the term "goodwill" occurring over the last few decades is found in the current definition of goodwill in Black's Law Dictionary. Lord Eldon [as well as Justice Story] might have recognized the first half of this definition . . . Black's initially focuses on a "business's reputation, patronage, and other intangible assets ... considered when appraising the business, esp. for purchase" but then adds "the ability to earn income in excess of the income that would be expected from the business viewed as a mere collection of assets ...." [T] he second half of Black's definition, the "excess income" notion, is solely based upon economic considerations and cannot be found in the line of cases stretching from Cruttwell through Smith, Morgan, and Bergamini to Dantonio.

Id. (citing BLACK's LAW Dictionary 703 (7th ed. 1999)); Lynda J. Oswald, Goodwill and Gong-Concern Value: Emerging Factors in the Just Compensation Equation, 32 B.C. L. REV. 283, 287-88 (1991).

In recent years, however, the definition of "goodwill" has evolved beyond this simple notion of patronage. For example, for purposes of tax law, goodwill is often defined as the excess earning power of a business, i.e., the value of elements such as trade names, trade brands, market acceptance, and established location that together create an expectancy of earnings in excess of the normal returns on the tangible assets.

Id.; Zipp, supra note 87, at 95 ("Originally, goodwill was said to exist only in commercial businesses and not to exist in a professional business which depends on the skill and reputation of a particular person. However, in recent years, courts have taken differing views in treating the existence and value of professional goodwill in divorce cases.").

120. See, e.g., In re Marriage of Nichols, 606 P.2d 1314, 1315 (Colo. Ct. App. 1979) (describing goodwill as "that portion by which the total value of a dental practice 


\section{OF CORPORATE \& FINANCIAL LAW}

Civil Procedure Code for instance, states that "goodwill consists of the benefits that accrue to a business as a result of its location, reputation for dependability, skill or quality, and any other circumstances resulting in probable retention of old or acquisition of new patronage." ${ }^{121}$ Definitions which emphasize individual goodwill constituents have been

exceeds the market value of the furniture, fixtures, and accounts receivable ...."); State v. Cowan, 103 P.3d 1, 5 (Nev. 2004) (describing goodwill as "imbu[ing] a business with value which cannot be accounted for by a mere examination of its physical or tangible assets; in short, where the whole business exceeds the sum of its tangible parts, business goodwill accounts for the additional value"); Russell v. Russell, 39 S.E.2d 166, 168 (Va. Ct. App. 1990) ("Goodwill has been defined as 'the increased value of the business, over and above the value of its assets, that results from the expectation of continued public patronage." (citing OLDHAM, DIVORCE, SEPARATION AND THE Distribution OF PROPERTY $\S 10.03$, at 10-20 (1989))); Rev. Rul. 68-609, 1968-2 C.B. 327 (requiring income from tangible assets to be subtracted from total income-the residual is capitalized and designated as goodwill); Rev. Rul. 59-60 § 4.02, 1959-1 C.B. 237 ("In the final analysis, goodwill is based upon earning capacity. The presence of goodwill and its value, therefore, rests upon the excess of net earnings over and above a fair return on the net tangible assets."); 38 AM. JUR. 2D Good Will § 4 ("A business ordinarily has some value above that of its assets, known as "good will value." (citing In re Marriage of Adams, 854 P.2d 501 (Or. Ct. App. 1993))); id. $§ 1$ ("“Good will' is an advantage or benefit acquired by a business beyond the mere value of its capital, stock, funds, or property employed." (citing Gilmore Ford, Inc. v. Turner, 599 So. 2d 29 (Ala. 1992))); 2-5 NICHOLS ON EMINENT DOMAIN, supra note 64, § 5.03.

Goodwill has been defined as: A going business has a value over and above the aggregate value of the tangible property employed in it. Such excess value is nothing more than the recognition that, used in an established business that has won the favor of its customers, the tangibles may be expected to earn in the future as they have in the past. Owners' privileges of so using them, and their privilege of continuing to deal with customers attracted by the established business, are property of value. This privilege is known as good-will.

Id.; BLACK's LAW DICTIONARY 763 (9th ed. 2009) (defining goodwill as "the ability to earn income in excess of the income that would be expected from the business viewed as a mere collection of assets."); 38 AM. JUR. 2D Good Will $\S 4$ ("Good will' is generally understood to represent the value of intangible factors that are expected to translate into greater than normal earning power, and, in addition to the advantageous relationship that a business enjoys with its customers, good will also includes advantageous relationships with employees, suppliers, lenders and others." (citing Bay Plastics, Inc. v. BT Commercial Corp., 187 B.R. 315 (Bankr. C.D. Cal. 1995))); Limitations on Recognitions for Equity Capital Purposes of Amounts Pade in Excess of Fair Market Value for Tangible Assets Acquired Prior to August 1970, 41 Fed. Reg. 46,292 (Oct. 20, 1976) (to be codified at 20 C.F.R. pt. 405) (referring to goodwill as "the attainment of profits in excess of a normal rate of return").

121. CAL. Civ. Proc. CODE $\S 1263.510$ (b) (West 2007). 
codified in state and federal statutes, ${ }^{122}$ and articulated in legal treatises, ${ }^{123}$ academic commentary, ${ }^{124}$ practitioner journals, ${ }^{125}$ as well as the common law. ${ }^{126}$ Professor Grace Ganz Blumberg cautions that any

122. See, e.g., UNIFORM EMINENT DOMAIN CODE $\S 1016$ (b) (1974) ("Within the meaning of this section, 'goodwill' consists of the benefits that accrue to a business as a result of its location, reputation for dependability, skill, or quality, and any other circumstances resulting in probable retention of old or acquisition of new patronage."); S.D. CODIFIED LAWS $\S$ 43-35-6 (2009); Wyo. STAT. ANN, § 1-26-713(b) (2009).

123. See, e.g., RUdolf CAllman, Unfair COMPETITION, TRADEMaRKS AND MONOPOLIES $\S 1.11$, at 1-58 (5th ed., rev. vol. 2003) ("Goodwill is not to be simply equated with reputation. It includes, but connotes more than, good credit, honesty, fair name and reliability. It may include technical efficiency."); 4-13 NICHOLS ON EMINENT DOMAIN, supra note $64, \S 13.18$ ("Goodwill' in the legal sense has come to mean the advantage that a business has over competitors as a result of its name, location, and owner's reputation."); BLACK'S LAW DICTIONARY 763 (9th ed. 2009) (defining goodwill as "[a] business' reputation, patronage, and other intangible assets that are considered when appraising the business, esp. for purchase . . "); 38 AM. JuR. 2D Good Will $\$ 5$ (citing Bay Plastics, Inc., 187 B.R. 315); Seiler v. Seiler, 706 A.2d 249, 251 (N.J. Super. Ct. App. Div. 1998) ("[G]oodwill includes a whole host of intangibles including quality of management, the ability of an organization to produce and market efficiently, and the existence and nature of competition." (citing Dugan v. Dugan, 457 A.2d 1, 5 (N.J. 1983))); 12B AM. JUR. PL. \& PR. FoRMS Goodwill $§ 1$ (Rev. 1999) ("Goodwill ... is an intangible business asset . . consisting of the value of the positive reputation of a business ... that is derived from the recognized quality of the product sold or the service performed, as well as other factors calculated to guarantee the continued patronage ... of the business ....").

124. See, e.g., Blumberg, supra note 74, at 221-22 (describing goodwill as "a constellation of inseparable intangible assets that inhere in a business or practice and enable it to realize supernormal earnings .... In addition to reputation and continuing patronage, goodwill may include, inter alia, strategic location, effective advertising, the value of a skilled, trained, efficient work force, assemblage of property, plant, and equipment in a productive unit, and systems, controls, and methods developed as part of the operation.").

125. See, e.g., Levis, supra note 64 , at 73 (describing goodwill as "that intangible asset arising as a result of name, reputation, customer loyalty, location, products, and similar factors not separately identified").

126. See, e.g., WMX Techs., Inc. v. Miller, 197 F.3d 367, 374 (9th Cir. 1999) (en banc) ("Essentially, the goodwill of a business . . . is made up of many factors, such as location, patronage of customers, relations with suppliers, experience of employees, effectiveness of management, and many other factors."); Westric Battery Co. v. Standard Elec. Co., 522 F.2d 986, 988 (10th Cir. 1975) (per curiam) (stating that goodwill is an intangible property interest "which attaches to a business on account of name, location, reputation for competency and the imponderables which cause buyers to return"); Redevelopment Agency of San Diego v. Attisha, 27 Cal. Rptr. 3d 126, 137 (Cal. Dist. Ct. App. 2005) (stating that the goodwill of a business includes benefits 


\section{OF CORPORATE \& FINANCIAL LAW}

attempt to list the assets that constitute goodwill is necessarily incomplete. Professor Blumberg explains that "[b]ecause goodwill is a residuum of assets we are otherwise unable to quantify individually, any listing of goodwill constituents is necessarily illustrative rather than exhaustive." 127

The modern legal approach to goodwill is illustrated by the decision of the Supreme Court of New Jersey, in Dugan v. Dugan. ${ }^{128}$ In Dugan, the plaintiff, James P. Dugan, and defendant, Rosaleen M. Dugan, were married for twenty years, until the marriage ended in divorce. The plaintiff maintained a law practice as a professional corporation, and the defendant worked as a secretary in the law office. The plaintiff's law practice was a major asset in the joint estate, and most of its value consisted of goodwill. ${ }^{129}$ The main issue in the case was the valuation and equitable distribution of the goodwill in the law practice. ${ }^{130}$ The

resulting from its "location, reputation for dependability, skill or quality, and any other circumstances resulting in probable retention of old or acquisition of new patronage"); Young v. Cooper, 203 S.W.2d 376, 384 (Tenn. Ct. App. 1947) (stating that many factors contribute to the value of the goodwill of a business, including "its reputation for doing business, the location, the number and character of its customers, the former success of the business, and many other elements which would be advantageous in the operation of the business"); State v. Cowan, 103 P.3d 1 (Nev. 2004) (observing that "[w]hile different jurisdictions vary slightly in their definitions of goodwill, the term generally is used to describe that component of value attributed to a business's reputation in the community, loyal customer base and ability to attract new customers"); Banner Milling Co. v. State, 191 N.Y.S. 143, 150 (N.Y. Ct. Cl. 1921) (“'Good will has been construed to include the value of brands, trademarks, a reputation for good product, fair and honorable dealing, and all those elements which contribute to the ready merchandising of the product of the company."); In re Marriage of Hall, 692 P.2d 175, 178 (Wash. 1984) (describing goodwill as "a distinct asset of a professional practice" which may exist "in the form of established patients or clients, referrals, trade name, location and associations ..." ).

127. Blumberg, supra note 74, at 221. See also Metro. Bank v. St. Louis Dispatch Co., 149 U.S. 436, 446 (1893) ("there is difficulty in deciding accurately what is included under the term [goodwill]"); Herbert D. Laube, Good Will in Professional Partnerships, 12 CORNELL L.Q. 303, 303 (1927) ("Good will is subtle and elusive. It is invisible and intangible. It has been variously defined. Chief Justice Fuller said that although undoubtedly in many cases it is a valuable thing, there is difficulty in deciding accurately what is included in the term." (quoting Metro. Bank v. St. Louis Dispatch Co., 149 U.S. 436, 446 (1893))); Blair \& Wallman, supra note 73, at 455 ("Goodwill, rather than referring to specific assets, is just a catch-all residual category ....").

128. Dugan v. Dugan, 457 A.2d 1, 5 (N.J. 1983).

129. Id. at 3.

130. Id. at 5 ("Our limited concern involves the existence of goodwill as property 
opinion presents a perceptive discussion of the economics and accounting of goodwill in a legal context.

The Court described goodwill as "the most intangible of the intangibles," but emphasized its importance as a "legally protected interest" $" 131$ and economic proxy for the reputation of a business. ${ }^{132}$ The Court acknowledged that "[w]hen goodwill exists, it has value and may well be the most lucrative asset of some enterprises." 133 It conceded the difficulty of valuing goodwill, but insisted that "difficulty in fixing its value does not justify ignoring its existence," should be valued with great care ...."135

After a brief nod to the classic definitions, ${ }^{136}$ the Court acknowledged the modern accounting view, stating that " $[t]$ he accounting profession has further expanded the concept of goodwill to encompass other advantages of an established business that contribute to its profitability," 137 including items not otherwise identifiable, such as "a good name, capable staff and personnel, high credit standing, reputation for superior products and services, and favorable location." 138 The opinion recognized the supranormal earnings and excess value view of goodwill, observing that "[g]oodwill can be translated into prospective earnings" over and above "the normal return on the investment." 139 It also recognized the role of specific reputational synergies that create supranormal earnings and value, stating that goodwill comes into existence and assumes value when earning capacity has been enhanced

and its evaluation for purposes of equitable distribution.").

131. Id. at 4 .

132. Id. at 6 ("Though other elements may contribute to goodwill in the context of a professional service, such as locality and specialization, reputation is at the core."); id. at 431 ("Goodwill is keyed to reputation ....").

133. Id. at 5.

134. Dugan v. Dugan, 457 A.2d 1, 7 (N.J. 1983).

135. Id.

136. Id. at 3-4 (citing In re Brown, 150 N.E. 581, 582 (N.Y. 1926)); Cruttwell v. Lye, (1810) 34 Eng. Rep. 129 (Ch.); STORY, supra note 114, at 157-61).

137. Id. at 4 .

138. Id. (citing J.M. SMITH \& K.F. SKOUSEN, INTERMEDIATE ACCOUNTING 283 (7th ed. standard vol. 1982)). See also id. at 4-5 ("In a broad sense goodwill includes a whole host of intangibles including the quality of management, the ability of the organization to produce and market efficiently, and the existence and nature of competition.").

139. Id. at 5 (citing George T. Walker, Why Purchased Goodwill Should Be Amortized on a Systematic Basis, 95 J. ACCOUNTANCY 210, 213 (1953)). 
because "reputation leads to probable future patronage from potential and existing clients." 140 The Court observed that the financial value of goodwill equals the present value of the excess earnings attributable to it, ${ }^{141}$ and that the value of the goodwill of a publicly traded corporation is reflected in its stock price. ${ }^{142}$

Although the Dugan opinion focused narrowly on the existence and value of goodwill in a professional practice as a matrimonial asset, the Court emphasized that its legal and accounting analysis is universal. ${ }^{143}$ Other courts and commentators have agreed that "[the existence and valuation of] [g]oodwill is not dependent on the form of business organization," 144 since it represents universal economic concepts, namely excess earnings and value, whether in "a partnership, corporation, joint venture, or individual proprietorship." 145

\section{Goodwill Valuation Must be Based on Accepted Accounting Methods}

Courts require that goodwill be valued according to accepted accounting methods. ${ }^{146}$ Appellate courts have held that lower courts must stipulate on the record the factors and accounting method on which it based its valuation. Failure to do so will render the valuation unsupported by evidence, resulting in reversal and remand for proper findings. ${ }^{147}$

140. Dugan v. Dugan, 457 A.2d 1, 6 (N.J. 1983); id. at 3 ("[G]oodwill is essentially reputation that will probably generate future business.").

141. Id. at 5 ("The price paid for goodwill then is equivalent to the excess of actual earnings over expected earnings based on a normal rate of return on investment.").

142. Id. ("In a publicly held corporation one can determine the total value of a business whose stock is publicly traded and therefore its goodwill by the market price of the stock.").

143. Id. ("Variances in the forms of an enterprise do not eliminate goodwill, though they may affect its worth.").

144. Zipp, supra note 87, at 102. See also Scherzer v. Scherzer, 346 A.2d 434, 436 (N.J. Super. Ct. App. Div. 1975) (holding that the equitable distribution principle as applied to goodwill applies equally and in the same manner to an interest in an individual business and one held in corporate name and stating "[t]he form should not control."); 2 BORIS I. BITTKER, FEDERAL TAXATION OF INCOME, ESTATES AND GIFTS If 51.9.3, at 51-53 (1981) (stating that goodwill exists in personal service enterprises as well as other businesses).

145. Dugan, 457 A.2d at 5 (citing Grayer v. Grayer, 371 A.2d 753, 757 (N.J. Super. Ct. App. Div. 1977)).

146. See, e.g., In re Marriage of Luckey, 868 P.2d 189, 193 (Wash. Ct. App. 1994).

147. See, e.g., In re Marriage of Crosetto, 918 P.2d 954, 958 (Wash. Ct. App. 1996). 
The common law recognizes a variety of goodwill valuation methods, ${ }^{148}$ including the so-called straight capitalization and excess earnings methods. According to the straight capitalization method, the total value of a business is first obtained by discounting the free cash flows to the firm at its weighted average cost of capital. ${ }^{149}$ The value of the goodwill of the business is then determined by subtracting the aggregate value of the business' tangible and identifiable intangible assets from the total value of the business. The straight capitalization method is established in accounting, ${ }^{150}$ and recognized in the common law. ${ }^{151}$

The excess earnings method estimates the value of goodwill as the present value of the supranormal earnings stream attributed to it. ${ }^{152}$ The method defines excess earnings as earnings above a normal return on tangible and identifiable intangible assets. ${ }^{153}$ The excess earnings method is widely used by accountants in business valuation, ${ }^{154}$ and has been endorsed by the American Institute of Certified Public Accountants (AICPA) as a valid approach to business valuation. ${ }^{155}$ The excess

148. See, e.g., id. (listing five accounting methods that are generally recognized, and stating that factors such as the practitioner's age, reputation and skill should be used in conjunction with the valuation formula to calculate professional goodwill). See also In re Marriage of Luckey, 868 P.2d at 193; In re Marriage of Hall, 692 P.2d 175, 178 (Wash. 1984) (acknowledging three recognized accounting formulas for valuing goodwill).

149. A firm's free cash flows represent the amount available for distribution to the firm's claimholders after taxes and reinvestment. A firm's claimholders include stockholders, bondholders, and preferred stockholders. See, e.g., Damodaran, supra note 41 , at 382. A firm's weighted average cost of capital is a value-weighted average of its cost of equity and after-tax cost of debt. The weights are the market values of equity and debt as a fraction of the total value of the firm. See, e.g., ZVI BODIE ET AL., FINANCIAL ECONOMICS 489 ( 2 d ed. 2009).

150. See, e.g., Damodaran, supra note 41, ch. 15; Bryan Mauldin, Comment, Identifying, Valuing, and Dividing Professional Goodwill as Community Property at Dissolution of the Marital Community, 56 TUL. L. REV. 313, 332-33 (1981); Comment, The Recognition and Valuation of Professional Goodwill in the Marital Estate, 66 MARQ. L. REV. 697 (1983).

151. See, e.g., In re Marriage of Hall, 692 P.2d at 179 (endorsing and applying straight capitalization method in marital dissolution case).

152. See, e.g., Zipp, supra note 87, at 91. See also Dugan v. Dugan, 457 A.2d 1, 7 (N.J. 1983) (describing the excess earnings method as a capitalization of residual earnings); Blumberg, supra note 74, at 265.

153. See, e.g., Dugan, 457 A.2d at 5 .

154. See, e.g., Blumberg, supra note 74, at 242.

155. See American Institute of Certified Public ACCOUNTANTS, SMall 
earnings method is widely accepted in the common law, ${ }^{156}$ and the IRS frequently employs this method to value businesses for tax purposes. ${ }^{157}$

Acceptance by the common law of goodwill valuation methods based on straight capitalization and excess earnings constitutes an implicit legal endorsement of accountants' supranormal earnings and excess value characterization of goodwill.

\section{Law has Adopted Economic View of Goodwill}

The law has adopted the economic view of goodwill, which defines goodwill as a rent-generating financial asset, and explains its value in terms of productive synergies. This subsection establishes the following:

(1) The law recognizes goodwill as a value-relevant corporate asset.

(2) The law recognizes specific synergies through which goodwill creates value. It also recognizes the converse, namely that reputational harm impairs the synergies, leading to loss of goodwill. The resulting loss of goodwill is reflected in the value of the securities of a publicly traded corporation.

(3) Common and statutory law allow recovery for lost goodwill.

\section{Goodwill is a Value-Relevant Asset}

The common law views goodwill as a valuable economic asset, ${ }^{158}$

Business Consulting Practice Aid No. 8, Valuation of a Closely Held Business 13-14 (1987).

156. See, e.g., People ex rel. Dep't of Transp. v. Muller, 681 P.2d 1340, 1345 (Cal. 1984) (approving the excess earnings method of valuing goodwill); Dugan, 457 A.2d at 5; In re Marriage of Luckey, 868 P.2d 189, 193 (Wash. Ct. App. 1994) (accounting expert valued the goodwill of a medical practice using the excess earnings method).

157. See Rev. Rul. 59-60, 1959-1 C.B. 237.

158. See, e.g., Des Moines Gas Co. v. City of Des Moines, 238 U.S. 153, 165 (1915) ("That there is an element of value in an assembled and established plant, doing business and earning money, over one not thus advanced, is self-evident. This element of value is a property right, and should be considered in determining the value of the property, upon which the owner has the right to make a fair return ...."); Metro. Bank v. St. Louis Dispatch Co., 149 U.S. 436, 446 (1893) ("[G]ood will is in many cases a valuable thing, although there is difficulty in deciding accurately what is included under the term."); Smith v. Bull, 325 P.2d 463, 468 (Cal. 1958) (Goodwill of advertising firm constitutes an asset); Morgan v. Perhamus, 36 Ohio St. 517, 522 (1881) ("[The goodwill of] an established business . . . has . . . marketable value, whether . . . that of a 
which generates supranormal earnings in combination with the other assets of a business, ${ }^{159}$ and creates value equal to the present value of the supranormal earnings. ${ }^{160}$ In Spayd v. Turner, ${ }^{161}$ a case involving measurement and distribution of goodwill in a partnership dissolution, the court explained that "[f]uture earning capacity per se is not goodwill. However, when that future earning capacity has been enhanced because reputation leads to probable future patronage from existing and potential clients, goodwill may exist and have value." 162 The court concluded that when the supranormal earnings have been translated into excess value,

professional man or of any other person." (quoting WALTER B. LINDLEY, A TREATISE ON THE LAW OF PARTNERSHIP (London, Sweet \& Maxwell, Ltd., 1860))); Buckl v. Buckl, 542 A.2d 65, 70 (Pa. Super. Ct. 1988) (stating that the physical assets, financial assets and goodwill collectively comprise the total value of the firm); Bradford $v$. Montgomery Furniture Co., 92 S.W. 1104, 1109 (Tenn. 1906) (stating that "[t]he good will of a firm is a species of property, often very valuable and it may be sold and transferred"); 38 AM. JUR. 2D Good Will $\S 4$ ("Good will is intangible property that constitutes a valuable asset of the business of which it is a part, unless in a particular instance it is too uncertain and contingent in nature to be appraised." (citing Gilmore Ford, Inc. v. Turner, 599 So. 2 d 29 (Ala. 1992))). See also Carter, supra note 83, at 761 ("Goodwill is intangible and often its precise source is difficult to trace, but it is one of a firm's most valued assets because it is, by definition, a major reason for the consumer's choice among competing brands."); Alicia Brokars Kelly, Sharing a Piece of the Future Post-Divorce: Toward a More Equitable Distribution of Professional Goodwill, 51 RUTGERS L. REV. 569, 584 (1999) ("[E]ven though [professional] goodwill cannot be sold or transferred separately from the individual services of the professional, the 'asset' has value to the professional as an ongoing member of the profession or business."); Wilhite, supra note 65 , at 362 (stating that "a professional business' good reputation" is a valuable asset "which is essentially what its goodwill consists of ...").

159. See, e.g., State Dep't of Transp. v. Cowan, 103 P.3d 1, 9 (Nev. 2004) ("[Goodwill] imbues a business with value which cannot be accounted for by a mere examination of its physical or tangible assets; in short, where the whole business exceeds the sum of its tangible parts, business goodwill accounts for the additional value." (citing Nichols ON EMINENT DOMAIN § 29.01[1] (2009))); Dugan, 457 A.2d at 5 ("Goodwill can be translated into prospective earnings."); In re Marriage of Crosetto, 918 P.2d 954, 958 (Wash. Ct. App. 1996) (recognizing goodwill as an asset "which usually supplements the earning capacity of another asset, a business or a profession" (citing In re Marriage of Hall, 692 P.2d 175, 178 (Wash. 1984))).

160. See, e.g., Dugan, 457 A.2d at 5. See also Rev. Rul. 59-60, 1959-1 C.B. 237 ("In the final analysis, goodwill is based upon earning capacity. The presence of goodwill and its value, therefore, rests upon the excess of net earnings over and above a fair return on the net tangible assets.").

161. Spayd v. Turner, 482 N.E.2d 1232 (Ohio 1985).

162. Id. at 1239 (emphasis added). 


\section{"the resulting goodwill [would be] property subject to equitable distribution." 163}

Courts have assigned a value to goodwill in a variety of legal contexts, including partnership, ${ }^{164}$ bankruptcy, ${ }^{165}$ corporate law, ${ }^{166}$ antitrust, ${ }^{167}$ condemnation, ${ }^{168}$ family law, ${ }^{169}$ probate, ${ }^{170}$ partnership, ${ }^{171}$

163. Id. See also W. Union Tel. Co. v. Poe, 61 F. 449, 456-57 (S.D. Ohio 1894).

The annual earnings of a business corporation depend, not on the value of the visible, tangible property of the corporation as a passive investment, like real estate or government bonds or mortgages, but they depend on the good will of the business, its volume, the speed with which the money capital can be turned over, the business skill and experience and economy of its management .... [T] he elements that are united to produce those earnings are not all, or a majority of them, in the form of tangible property, though it may be conceded that they were acquired by investing tangible capital. A corporation does not own its capital stock, divided into shares. It owns the property which, when used in a business with skill and industry, aided by the good will . . . will produce the net earnings, out of which the dividends on the stock are to be paid. This is true of all active business corporations ... that their annual profits are the result, not of their real estate, business plant, and merchandise only, but of those things united with the good will and the skill, experience, and economy used in the conduct of the business.

Id.

164. See, e.g., Spayd, 482 N.E.2d at 1236 ("Generally, a partnership business may build goodwill as an asset, and upon dissolution of the business by one or more of the partners, courts have recognized that measurable goodwill is a proper asset for consideration in an accounting between the partners ....").

165. See, e.g., Mut. Life Ins. Co. v. Menin, 115 F.2d 975, 977 (2d Cir. 1940) (goodwill as asset subject to powers of trustee in bankruptcy), cert. denied, 313 U.S. $578(1941)$.

166. See, e.g., Washburn v. Nat'l Wall-Paper Co., 81 F. 17, 20 (2d Cir. 1897).

167. See, e.g., Standard Oil Co. v. Moore, 251 F.2d 188, 219-20 (9th Cir. 1957).

168. See, e.g., Kimball Laundry Co. v. United States, 338 U.S. 1 (1949); People ex rel. Dep't of Transp. v. Muller, 681 P.2d 1340 (Cal. 1984).

169. See, e.g., Mitchell v. Mitchell, 732 P.2d 208, 212 (Ariz. 1987) (recognizing "the economic reality that the goodwill of a professional practice has value, and [that] it should be treated as property upon dissolution of the community . . "); Prahinski v. Prahinski, 540 A.2d 833, 841 (Md. Ct. Spec. App. 1988) (stating that "[i]f it does exist, ... goodwill is an asset to be valued and considered in equitable distribution"); In re Marriage of Luckey, 868 P.2d 189, 193 (Wash. Ct. App. 1994). See also Comment, Professional Goodwill in Louisiana: An Analysis of Its Classification, Valuation and Partition, 43 LA. L. REV. 119, 121 (1982) (valuation of goodwill in professional practice in marital resolution).

170. See, e.g., In re Whalen, 246 N.Y.S.2d 327, 331 (Sur. Ct. N.Y. 1963) (goodwill as subject of testamentary bequest); Copland v. Wis. Dep't of Taxation, 114 N.W.2d 858, 864-67 (Wis. 1962).

171. See, e.g., Lyon v. Lyon, 54 Cal. Rptr. 829 (Cal. Ct. App. 1966); Murray v. Bateman, 51 N.E.2d 954 (Mass. 1943). 
taxation, ${ }^{172}$ and tort. ${ }^{173}$

\section{Law Recognizes Specific Synergies}

The common law, supported by statutes and academic commentary, recognizes specific synergies through which goodwill creates value. These synergies include items related to reputation, such as patronage, ${ }^{174}$

172. See, e.g., Houston Chronicle Publ'g Co. v. United States, 481 F.2d 1240, 1248 (2d Cir. 1973) (stating that "the economic value of a taxpayer's continuing goodwill within his field of operations is seen as an ongoing asset that fluctuates but does not necessarily diminish"); Mut. Life Ins. Co. v. Menin, 115 F.2d 975, 977 (2d Cir. 1940) (goodwill as taxable item), cert. denied, 313 U.S. 578 (1941); Courier Journal Job Printing Co. v. Glenn, 37 F. Supp. 55, 59-60 (W.D. Ky. 1941), aff'd, 127 F.2d 820 (6th Cir. 1942). See also Edward J. Schnee, Acquiring Assets by Purchasing Corporate Stock, 13 TAX ADVISER 354, 361-63 (1982); Note, Valuation of Goodwill for Tax Purposes, 48 VA. L. REV. 1274 (1962).

173. See, e.g., Carrey v. Boyes Hot Springs Resort, Inc., 54 Cal. Rptr. 199, 245 (Cal. Dist. Ct. App. 1966). See also 16 AM. JUR. 2D Proof of Facts $\S 253$ (2009).

174. See, e.g., Agric. Servs. Ass'n, v. Ferry Morse Seed Co., 551 F.2d 1057, 1071 (6th Cir. 1977); Houston Chronicle Publ'g Co., 481 F.2d at 1248 (describing "the ongoing expectation that customers would utilize its services in the future" as the "archetypical element of goodwill" (citing J.C. Cornillie Co. v. United States, 298 F. Supp. 887 (E.D. Mich. 1968))); Comm'r v. Killian, 314 F.2d 852, 855 (5th Cir. 1963); Boe v. Comm'r, 307 F.2d 339, 343 (9th Cir. 1962) ("[T]he essence of goodwill is the expectancy of continued patronage, for whatever reason."); Nelson Weaver Realty Co. v. Comm'r, 307 F.2d 897, 901 (5th Cir. 1962); Burke v. Canfield, 121 F.2d 877, 880 (D.C. Cir. 1941).

It is not necessary to consider exhaustively what constitutes good will. It is of course characteristic of a going business and essentially is constituted in the tendency of customers to return for trade to those with whom they are accustomed to deal. Many and varied elements may hold out the lure to return. They include an established trade name, a specific or general location, a reputation for service, personal attention, reasonable prices, etc.

Id.; Eslami v. Eslami, 591 A.2d 411, 418 (Conn. 1991).

It can hardly be doubted that the increment of value, loosely termed goodwill, that arises from the established reputation of a business for the quality of its goods or services may often be found to enhance the value of professional as well as other enterprises by increasing their ability to attract patrons.

Id.; 38 AM. JUR. 2D Good Will $\S 1$ ("When a business' future earning capacity has been enhanced because its reputation leads to probable future patronage from existing and potential clients, good will may exist and have value." (citing Seiler v. Seiler, 706 A.2d 249 (N.J. Super. Ct. App. Div. 1998))). See also Steven M. Auvil, Gray Market Goods Produced by Foreign Affiliates of the U.S. Trademark Owner: Should the Lanham Act Provide a Remedy?, 28 AKRON L. REV. 437, 448 (1995).

[A]ssuming the producer expends the necessary resources on quality, service and 
a sound credit rating, ${ }^{175}$ favorable location, ${ }^{176}$ public confidence ${ }^{177}$ and sound relations with regulatory authorities, employees and suppliers. ${ }^{178}$

advertising, the reputation of the [producer's] trademark will allow the producer to take advantage of the higher sales that flow from the willingness of consumers to pay higher prices in exchange for lower search costs and the assurance of consistent Id. quality.

175. See, e.g., 38 AM. JUR. 2D Good Will $\S 1$ (emphasizing value of advantageous relationships with parties such as financiers (citing In re Corrugated Paper Corp., 185 B.R. 667 (Bankr. D. Mass. 1995))). See also Andres Cowan, Note, Scarlet Letters for Corporations? Punishment by Publicity Under the New Sentencing Guidelines, 65 S. CAL. L. REV. 2387, 2398-99 (1992) ("A good image . . . may make financial institutions more likely to extend credit during difficult times.").

176. See, e.g., Winn-Dixie Montgomery, Inc. v. United States, 444 F.2d 677, 681 (5th Cir. 1971) ("Location may indeed be a key element in retail food store patronage, but to the extent location contributes to the expectancy that the old customers will resort to the old place it is an element of goodwill." (citing Comm'r v. Seaboard Fin. Co., 367 F.2d 646, 651 n.6 (9th Cir. 1966))); Burke, 121 F.2d at 880.

It is not necessary to consider exhaustively what constitutes good will. It is of course characteristic of a going business and essentially is constituted in the tendency of customers to return for trade to those with whom they are accustomed to deal. Many and varied elements may hold out the lure to return. They include an established trade name, a specific or general location, a reputation for service, personal attention, reasonable prices, etc.

Id. See also Note, Amortization of Intangibles: An Examination of the Tax Treatment of Purchased Goodwill, 81 HARV. L. REV. 859, 861 (1968) ("The most important producer of excess earnings is 'carryover' customer satisfaction which takes the form of continuing patronage. Customers may be satisfied only in the sense that a certain business is conveniently located for their needs; indeed, location was originally considered to be the sine qua non of goodwill.").

177. See, e.g., Des Moines Gas Co. v. Des Moines, 238 U.S. 153, 164-65 (1915) (referring to goodwill as "that element of value which inheres in the fixed and favorable consideration of customers, arising from an established and well-known and wellconducted business ... ."); W. Union Tel. Co. v. Poe, 61 F. 449, 457 ( S.D. Ohio 1894) ("The increase in the value of the bank's capital stock over its resources is due to the good will which invites the confidence of the public in the honesty and prudence of its management, and attracts deposits and business ....").

178. See, e.g., 38 AM. JUR. 2D Good Will $\S 1$.

This "'positive reputation"“ manifests itself as an expectancy that a business has of continued patronage from its customers. The source of that expectancy may be the advantageous relationships the business has with parties such as employees, suppliers, or financiers, or it may be the location of the business or its general reputation.

Id. (citing In re Corrugated Paper Corp., 185 B.R. 667 (Bankr. D. Mass. 1995)). See also Cowan, supra note 175, at 2399 ("A good image may make it easier for the company to attract investors and talented management .... Company lobbyists may be seen as more credible when they lobby for or against legislation affecting the 
Law \& Economics scholars, Professors William M. Landes and Richard A. Posner, describe synergies related to sales and patronage, observing that "once the reputation [of a brand] is created, the [owner of the brand name] will obtain greater profits because repeat purchases and word-ofmouth references will generate higher sales and because consumers will be willing to pay higher prices for lower search costs and greater assurance of consistent quality." ${ }^{179}$ The common law also recognizes the converse, namely that reputational harm may impair the synergies that create supranormal earnings and value, resulting in loss of goodwill. ${ }^{180}$

Courts have allowed plaintiffs to recover damages for lost goodwill. ${ }^{181}$ In National Association for the Advancement of Colored

industry.").

179. Landes \& Posner, supra note 88, at 270.

180. See, e.g., Warner-Lambert Co. v. Northside Dev. Corp., 86 F.3d 3, 8 (2d Cir. 1996) (stating that "[b]ad experiences by concentrations of consumers can lead to communications that mutually reinforce negative impressions about a mark and cause substantial numbers of consumers and chains to cease purchasing products using the mark"); Dodge Bros. v. United States, 118 F.2d 95, 100 (4th Cir. 1941) (stating that the value of goodwill "fluctuates in direct relationship with the annual variations in the profits of the business with which it is associated"); Red Wing Malting Co. v. Willcuts, 15 F.2d 626, 632 (8th Cir. 1926) ("If earnings decline for any reason, the value of good will declines correspondingly, because by its very nature its value depends on earnings of a certain amount being maintained." (citing ROBERT H. MONTGOMERY, AUDITING THEORY AND PRACTICE 123 (Ronald Press Co., 5th ed. 1921))); W. Union Tel. Co., 61 F. at 457 (stating that changes in the earnings of a corporation do not affect the market value of its tangible and identifiable intangible assets, but do affect the value of its goodwill); Wingate Prettyman v. Shockley, 4 Del. (4 Harr.) 112, 114 (Del. Super. Ct. 1844) (holding that a defamatory publication harmful to a business's perceived creditworthiness may result in monetary loss, which plaintiff may recover as special damages, if proven). See also Herzfeld, supra note 19, at 142 (stating that a defamatory publication "could reduce [the plaintiff corporation's] future profits and the value of its goodwill, which are both forms of injury to business reputation").

181. See, e.g., Am. Online, Inc. v. LCGM, Inc., 46 F. Supp. 2d 444, 450 (E.D. Va. 1998) (finding that 18 U.S.C. $\S 1030(a)(5)$ allows recovery for loss of reputation and goodwill); Muraco v. Don, 250 P. 1109, $1111-12$ (Cal. Ct. App. 1926) (Defendant sold his business, including its goodwill, to the plaintiff. The defendant then diverted his old customers to another business, for which he received a commission. The court held that the resulting loss of patronage impaired the goodwill conveyed, for which the plaintiff may recover.); Avery v. City of Lyons, 331 P.2d 906, 914 (Kan. 1958) (harm to business's goodwill taken into account in damages estimate); Texas \& Pac. Ry. Co. v. Mercer, 90 S.W.2d 557, 560 (Tex. 1936) (allowing plaintiff to recover for harm to goodwill of his dairy farm caused by defendant's unauthorized obstruction of a 


\section{OF CORPORATE \& FINANCIAL LAW}

People v. Overstreet, ${ }^{182}$ the Georgia Supreme Court affirmed a jury verdict awarding the respondent damages for goodwill lost due to unlawful picketing of his business. The respondent, Haldred Overstreet, had owned and operated a retail grocery store in Savannah for 16 years, and had built up considerable goodwill in his business. ${ }^{183}$ In May 1962, a 14-year-old African American youth complained to the local police that he had been abused by the respondent. ${ }^{184}$ The youth's mother contacted the Savannah Branch of the National Association for the Advancement of Colored People, who responded by organizing a campaign to picket Overstreet's store. ${ }^{185}$ The picketing attracted substantial crowds, and there were incidents involving the intimidation of customers, obstruction of public sidewalks and streets, and some violence. ${ }^{186}$

Overstreet filed suit against the national NAACP, the Savannah Branch of the NAACP, The Georgia State Conference of Branches of the NAACP, and one W. W. Law, the president of both the Savannah Branch of the NAACP and the Georgia State Conference of Branches of the NAACP. The petition alleged loss of goodwill in the amount of forty thousand dollars. ${ }^{187}$ The plaintiff also claimed an additional forty thousand dollars in punitive damages. ${ }^{188}$ The jury awarded the plaintiff compensatory damages of $\$ 35,793$ and punitive damages of $\$ 50,000$.

Defendants appealed to the Georgia Supreme Court, which reversed the lower court's decision against the Georgia State Conference of Branches of the NAACP, but affirmed as to all other defendants. The Court observed that goodwill is uniformly recognized as property and a

highway); LAWrenCE Sullivan, HANDBOOK OF THE LAW OF ANTITRUST $\S 251$, at 787 (1977) (loss of goodwill recognized as recoverable harm under the antitrust treble damages provision); Harry D. Nims, Damages and Accounting Procedure in Unfair Competition Cases, 31 CoRNell L.Q. 431 (1946); Floyd A. Wright, Tort Responsibility for Destruction of Goodwill, 14 CORNELL L.Q. 298, 307 (1929); Comment, Loss of Goodwill and Business Reputation as Recoverable Elements of Damages Under Uniform Commercial Code § 2-715-The Pennsylvania Experience, 75 DICK. L. REV. 63 (1970).

182. NAACP v. Overstreet, 142 S.E.2d 816 (Ga. 1965).

183. Id. at 821 ("[Respondent grocery store owner] had created good will and good faith in the course of his business with the public.").

184. Id.

185. Id. at $821-22$.

186. Id. at 825 .

187. Id. at 822 .

188. NAACP v. Overstreet, 142 S.E.2d 816, 822 (Ga. 1965). 
valuable business asset. ${ }^{189}$ It stated that harm to business goodwill constitutes a cause of action for the resulting damages, and that the plaintiff had provided evidence of his pecuniary loss. ${ }^{190}$ The Court held that evidence of lost earnings proximately caused by the defendant's illegal picketing "[supported] a finding that [plaintiff] suffered more than the $\$ 40,000$ in actual damages." It upheld the lower court's award of $\$ 35,793.05$ as compensatory damages for lost goodwill, concluding that it was consistent with the evidence. ${ }^{191}$

Recovery of damages for lost goodwill has statutory support. ${ }^{192}$ Section 1016 of the Uniform Eminent Domain Code, for instance, provides for compensation for lost goodwill to businesses displaced by eminent domain. ${ }^{193}$ Although California courts historically denied recovery for goodwill in condemnation actions, ${ }^{194}$ the State was an early adopter of the language of the Uniform Eminent Domain Code. The California Code of Civil Procedure now provides for compensation for loss of goodwill in takings occurring in California after July $1,1976 .{ }^{195}$ The provision defines goodwill in terms of value realized from patronage. ${ }^{196}$ In People ex rel. Department of Transportation $v$. Muller, ${ }^{197}$ the Court confronted, and resolved the issue whether the statutory definition of goodwill should be interpreted narrowly as

189. Id. at 827 .

190. The plaintiff provided evidence that his "net income from his business for the twelve months preceding the picketing was $\$ 3,018.26$ and he suffered a loss of $\$ 952.19$ during the twelve months following the beginning of the picketing," and that his loss would have been much greater had he not taken certain cost mitigating measures. Id.

191. See id. at 827-28.

192. See, e.g., NEV. REV. STAT. ANN. \$ 37.111(1) (2005) (allowing compensation for loss of goodwill in eminent domain, provided specified conditions are met).

193. See UnIForm EMINENT Domain CODE § 1016. See also S.B. No. 460, 148th Gen. Assem., Reg. Sess. (Ga. 2006) (providing that damages for displacement may include "the loss in value of the goodwill of any business located on such property as a result of the taking and the resulting need to relocate such business ... ").

194. See, e.g., City of Oakland v. Pac. Coast Lumber \& Mill Co., 153 P. 705, 707 (Cal. 1915).

195. See Cal. Crv. Proc. Cone $\S 1263.510$ (West 1982).

196. See id. at $\S 1263.510(\mathrm{~b})$ (defining goodwill as consisting of "the benefits that accrue to a business as a result of its location, reputation for dependability, skill or quality, and any other circumstances resulting in probable retention of old or acquisition of new patronage"). Other Califormia statutes also define goodwill in terms of the expectancy of continuing patronage. See, e.g., CAL. BUS. \& PROF. CODE $\S 14100$ (West 1987).

197. See People ex rel. Dep't of Transp. v. Muller, 681 P.2d 1340 (Cal. 1984). 


\section{OF CORPORATE \& FINANCIAL LAW}

relating only to patronage.

In Muller, the Department of Transportation took the land on which Dr. Muller's veterinary clinic was located. Muller relocated his practice without loss of patronage or gross income, but his expenses, including his rent, increased, resulting in a loss in net income and goodwill. The Department of Transportation argued that the statute should be interpreted narrowly as allowing compensation only for goodwill losses due to loss of patronage. ${ }^{198}$ The government contended that it therefore owed no compensation for goodwill, since Muller's loss was due to an increase in business expenses unrelated to patronage. ${ }^{199}$ The Court rejected the Department's limited interpretation of the statute and endorsed an expansive definition of goodwill. ${ }^{200}$ It interpreted the statute as authorizing compensation for lost benefits associated with location, but stressed that patronage is not the only benefit associated with a favorable location. In the present case the plaintiff retained patronage, but lost certain cost advantages associated with his prior location. ${ }^{201}$ The Court's broadened interpretation of goodwill entitled the plaintiff to recover this loss.

\section{Value of Goodwill Reflected in Stock Price}

The common law, ${ }^{202}$ including opinions by the United States

198. See id. at 1343.

199. Id.

200. See id. at 1344.

201. See id. at 1343.

202. See, e.g., Charter Wire, Inc. v. United States, 309 F.2d 878, 879 (7th Cir. 1962)

("The stock included the good will value of the enterprise."); Food Fair Stores, Inc. v.

Lakeland Grocery Corp., 301 F.2d 156, 158 (4th Cir. 1962) (stating that the value of the goodwill of a company as "measured by the market value of its stock in excess of its book value was $\$ 33,000,000 "$ "); Young v. Seaboard Corp., 360 F. Supp. 490, 497 (D. Utah 1973) (stating that the value of the shares of an ongoing concern includes the "good will value of the corporation"); Richland v. Crandall, 262 F. Supp. 538, 548-49 (S.D.N.Y. 1967) (stating that the market value of the company's shares "was not separable from the value of the business as a going concern, since it represented what willing buyers and sellers had negotiated repeatedly as the price for a proportionate share of the company's equity, including its good will"); W. Union Tel. Co. v. Poe, 61 F. 449, 457 (S.D. Ohio 1894).

The increase in the value of the bank's capital stock over its resources is due to the good will which invites the confidence of the public in the honesty and prudence of its management, and attracts deposits and business, and to the skill and experience and foresight of its officers in making profitable and safe loans. [T] he value of [the] 
Supreme Court, ${ }^{203}$ has recognized that the value of the goodwill of a business is included in its equity. In Dugan v. Dugan, ${ }^{204}$ the New Jersey Supreme Court stated explicitly that the value of goodwill is reflected in the stock price of a publicly traded company. ${ }^{205}$ In Diamond $v$. Oreamuno, ${ }^{206}$ a case involving allegations of insider trading, the court cautioned in dicta that the public reputation of a corporation may directly affect the market value of its securities. The court stated that corporate misconduct may injure a corporation's reputation for integrity and probity, and undermine the value of its securities. ${ }^{207}$ It explained that public perception of managerial integrity is essential to ensure sound investor relations and marketability of the shares of a company. ${ }^{208}$ These factors are related to investor perceptions of risk and liquidity, which are important determinants of the market value of a company's securities. $^{209}$

\section{The Economic View of Goodwill Supports Proximate Causality}

The tort doctrine of proximate cause limits a plaintiff's recovery to harm reasonably related to, or "proximately caused by," the defendant's wrongdoing. ${ }^{210}$ Foreseeability plays a central role in proximate cause. ${ }^{211}$

capital stock [of a corporation] is largely dependent on its good will, the honesty, skill, economy, and experience of its management and its employees, added to its property.

Id.

203. See, e.g., Home Sav. Bank v. Des Moines, 205 U.S. 503, 512 (1907) (stating that goodwill is an essential component of the total value of the shares of a bank).

204. See Dugan v. Dugan, 457 A.2d 1 (N.J. 1983).

205. See id. at 5 ("In a publicly held corporation one can determine the total value of a business whose stock is publicly traded and therefore its goodwill by the market price of the stock."). See also Red Wing Malting Co. v. Willcuts, 15 F.2d 626, 633 (8th Cir. 1926) ("In [the] case of a public company, the good will is known from day to day." (citing Higher ACCOUNTANCY Principles and PRACTICE (William Arthur Chase ed., 1914))).

206. Diamond v. Oreamuno, 248 N.E.2d 910 (N.Y. 1969).

207. Id. at 912 .

208. Id. at 912 (citing Diamond v. Oreamuno, 29 A.D.2d 285, 287 (N.Y. App. Div. 1968)).

209. See, e.g., Jonathan Berk \& Peter DeMarzo, Corporate finance: The CORE 405 (Pearson Publ'g Co., 2009); id. at 12 ("[A]n important feature of an investment in the equity of a corporation is its liquidity.").

210. See Mark F. Grady, Proximate Cause Decoded, 50 UCLA L. REV. 293 (2002).

211. See, e.g., MARC A. FrankLIN \& Robert L. RABIN, TORT LAW AND 
Commenting on the role of foreseeability, Professor Jonathan Cardi states: "a plaintiff may fail to survive the proximate cause inquiry where the defendant's actions resulted in:

(1) an unforeseeable type of injury;

(2) an injury occurring in an unforeseeable manner; or

(3) injury to an unforeseeable plaintiff. ${ }^{212}$

An event is considered the foreseeable result of an action if the action ex ante systematically increased the likelihood of the event. This would be the case if the action either created the risk of the event or increased the likelihood of its materialization. ${ }^{213}$ The basic test of foreseeability can also be described as "whether one can see a systematic relationship between the type of [harm] that the plaintiff suffered and the defendant's [action]."214 Coincidental harm would therefore not be considered foreseeable. ${ }^{215}$

Alternatives 399 (Foundation Press, Inc., 7th ed. 2001); Grady, supra note 210, at 322-32 (discussing the reasonable foresight paradigms of proximate cause).

212. W. Jonathan Cardi, Purging Foreseeability: The New Vision of Duty and Judicial Power in the Proposed Restatement (Third) of Torts, 58 VAND. L. REV. 739, 749 (2005).

213. See Grady, supra note 210 , at 323 (stating that the plaintiff must show that an untaken precaution would have reduced the risk of the accident at issue. If not, the plaintiff fails on proximate cause grounds.). See also Stephen R. Perry, Responsibility for Outcomes, Risk, and the Law of Torts, in PHILOSOPHY AND THE LAW OF TORTS 72, 98 (Gerald J. Postema ed., 2001) (explaining that proximate causation views the plaintiff's harm "from the standpoint of an appropriately general description of the risk created by the defendant").

214. See Grady, supra note 210 , at 323 .

215. Suppose, for instance, a defendant negligently exceeds the speed limit and arrives at a spot just in time to be struck by a falling tree. Although a plaintiff such as an injured passenger may argue credibly that falling trees are foreseeable, the accident is likely outside the scope of risk created by the defendant's speeding. The defendant's speeding created risks of traffic accidents, but it neither created the risk that materialized nor made it more likely. The accident was therefore not within the scope of foreseeable risk created by the defendant's conduct. The outcome would likely have been different if instead a tree had fallen in front of the speeding driver, and the car crashed into it. If it can be shown that the accident could have been avoided had the driver travelled at a reasonable speed, then the speeding driver's negligence may have been a proximate cause of the accident. Failure to stop within a short time window is a foreseeable risk of speeding. It is coincidental and not systematically related to the defendant's negligence, hence unforeseeable. See Berry v. Borough of Sugar Notch, $191 \mathrm{~Pa} .345$ (1899); see also Grady, supra note 210, at 324. 
The proximate cause doctrine, including its foreseeability inquiry, applies to the tort of defamation. ${ }^{216} \mathrm{~A}$ defendant in a defamation case is therefore liable only for reputational harm proximately caused by its defamatory publication. The common law's adoption of the economic view of goodwill implies legal recognition of a proximate causal relationship between reputational harm and loss of goodwill. Reputation and goodwill are systematically connected through the economic synergies by which reputation adds value to goodwill, and which are harmed when the company is defamed. A defamation plaintiff may therefore recover damages for lost goodwill, but any recovery must be adjusted to exclude goodwill losses due to factors unrelated to the defendant's wrongdoing.

\section{Evidence of Special Damages: The Legal BASIS FOR A CAPITAL MARKET APPROACH}

This Section draws on the analysis of corporate reputation and its relation to goodwill, as well as the legal, accounting, and economic meanings of goodwill, developed in previous sections, to construct a legal basis for a capital market approach to proving and measuring special damages. The results of the analysis can be summarized as follows:

1. The substantive right guarded by defamation law is the integrity of a plaintiff's reputation.

2. The law views the reputation of a corporation as a core element of its goodwill.

216. See, e.g., Keeton v. Hustler Mag., Inc., 465 U.S. 770, 776 (1984) ("[A] tortfeasor shall be liable for damages which are the proximate result of his tort . . . This interest extends to libel actions brought by nonresidents."); Georgia v. Kepford, 45 Iowa 48 (1876); Field v. Colson, 20 S.W. 264 (Ky. 1892); Lopez v. Kline, 953 P.2d 304, 308 (N.M. Ct. App. 1997) (stating that "[p]roximate cause is an element of defamation"); DAN B. DOBBS, LAW OF REMEDIES: DAMAGES - EQUITY - RESTITUTION $§$ 7.2 (2d ed. 1993) (discussing defamation, generally); PROSSER, supra note $6, \S \S 116$, 112 ("So far as proximate cause is concerned, recovery has been limited very definitely to those damages which are regarded as reasonably foreseeable or normal consequences of the defamation." (citing Lynch v. Knight, (1861) 9 H.L.C. 577, 11 Eng. Rep. 854)); Ellyn T. Marcus, Comment, Group Defamation and Individual Actions: A New Look at an Old Rule, 71 CAL. L. REV. 1532, 1555 (1983) ("A plaintiff who wished to prove special damages had to demonstrate that such damages proximately resulted from the defamation." (citing LAURENCE EldREDGE, THE LAW OF DefaMation $§ 2$ (1978))). 
3. The law recognizes goodwill as a value-relevant financial asset.

4. The law recognizes that a positive reputation adds value to a corporation's goodwill through economic synergies with its tangible and identifiable intangible assets. It also recognizes the converse, namely that reputational harm impairs these synergies, resulting in loss of goodwill. The law therefore recognizes that reputational harm due to defamation proximately causes financial loss in the form of lost goodwill.

5. Common and statutory law allow recovery for lost goodwill.

6. The common law recognizes that the value of the goodwill of a business is part of its equity, and in the case of a publicly traded corporation, reflected in its stock price.

7. Evidence of special damages in a defamation action must prove (1) the loss of something having financial value; and (2) that the loss is the proximate result of reputational injury caused by the defamation. $^{217}$

Results 1-7 imply that the law recognizes (1) a systematic causal relationship between reputational harm and loss of goodwill, and (2) that loss of goodwill is reflected in a decline in the value of the shares of a defamed corporation. A decline in the share price of a defamed corporation, adjusted for factors unrelated to the defamation, therefore constitutes legally valid evidence of special damages for the plaintiff's reputational harm. The adjustment for unrelated factors is necessary to satisfy proximate cause.

Economists and statisticians have developed a powerful statistical methodology, known as an "event study," that can be applied to assess special damages. ${ }^{218}$ An event study measures the impact of an economic "event" on the share price of a corporation. ${ }^{219}$ Researchers have, for

217. See, e.g., I SACK, supra note 3, $§ 10.3 .2$ ("Special damages are damages awarded to compensate the plaintiff for actual pecuniary loss .... The pecuniary loss comprising special damages must flow directly from the injury to reputation caused by the defamation.").

218. See, e.g., Sanjai Bhagat \& Roberta Romano, Event Studies and the Law: Part I (Technique and Corporate Litigation), 4 AM. L. \& ECON. REV. 141 (2002); Sanjai Bhagat \& Roberta Romano, Part II (Empirical Studies of Corporate Law), 4 AM. L. \& ECON. REV. 380 (2002).

219. See, e.g., In re World Access, Inc., 310 F. Supp. 2d 1281, 1299 (N.D. Ga. 2004) ("An event study is a statistical regression analysis that examines the effect of an event, such as an allegedly fraudulent statement or omission, on a dependent variable, such as a company's stock price."); Jonathan R. Macey et al., Lessons from Financial 
instance, used event studies to measure the impact of the announcement of a criminal investigation on the share price of the target of the investigation. ${ }^{220}$

Measurement of the impact of an event on a share price is complicated when the share price moves not only in response to the event, but also in response to simultaneous unrelated factors. A defamatory publication may, for instance, coincide with an unanticipated increase in interest rates. The interest rate increase and the defamation may both contribute to a decline in the share price of the corporation. The mathematical principles underlying the event study methodology enable it to distinguish between the event of interest and unrelated confounding events. ${ }^{221}$ A well-designed event study can therefore isolate the effect of a defamatory publication from the effects of other factors, in order to provide an estimate of the portion of the defamed company's share price change solely due to the defamation. ${ }^{222}$ Such an estimate, if properly executed, would provide a measure of a plaintiff's reputational harm proximately caused by the defamation. ${ }^{223}$

The event study methodology, and its application in various legal contexts, have been widely accepted in the common law. ${ }^{224}$

Economics: Materiality, Reliance, and Extending the Reach of Basic v. Levinson, 77 VA. L. REV. 1017, 1028 (1991) (describing an event study as "an empirical technique for determining how securities returns react to new information").

220. See, e.g., Karpoff et al., supra note 92, at 581.

221. See, e.g., Sanjai Bhagat \& Roberta Romano, Event Studies and the Law: Part I (Technique and Corporate Litigation), 4 AM. L. \& ECON. REV. 141, 143-47 (2002).

222. See, e.g., Ronald J. GILSON \& Bernard S. BLACK, The Law \& FinANCE of CORPORATE ACQuisitions ch. 6 (Foundation Press, Inc., 2d ed. 1995).

223. Event studies measure the reaction of security prices to new information, and are therefore most effective and reliable when applied to share prices in an efficient market. An "efficient market" is commonly defined as a market in which stock prices rapidly incorporate new publicly available information. See, e.g., Berk \& DeMarzo, supra note 209 , at 313-15.

224. See, e.g., Basic v. Levinson, 485 U.S. 224, 247 (1988) (relying on empirical studies showing that securities prices react quickly to the release of new information); In re N. Telecom Ltd., 116 F. Supp. 2d 446, 460 (S.D.N.Y. 2000) (holding that expert testimony is "fatally deficient in that [the plaintiff's expert] did not perform an event study or similar analysis to remove the effects on stock price of market and industry information"); In re Oracle Sec. Litig., 829 F. Supp. 1176, 1181 (N.D. Cal. 1993) ("Use of an event study or similar analysis is necessary more accurately to isolate the [specific] influences ... which defendants allegedly have distorted."). See also Janet Cooper Alexander, The Value of Bad News in Securities Class Actions, 41 UCLA L. REV. 1421, 1428-62 (1994); Bradford Cornell \& R. Gregory Morgan, Using Finance 


\section{CONCLUSION}

This Article has established that a decline in the value of the securities of a defamed corporation, adjusted for factors unrelated to the defamation, constitutes legally valid evidence of special damages for reputational harm. This approach has a sound theoretical and empirical economic basis. Economic theory predicts that a defamatory publication may harm a company's earnings, leading to a decline in the value of its goodwill and stock price. Empirical studies confirm that the stock market imposes reputational penalties on defamed corporations. This article establishes the legal basis and validity of a capital market approach to damages. It starts from first principles, by considering the substantive right protected by defamation law, namely the integrity of a plaintiff's reputation, and proceeds with an analysis of its legal concept as a core element of goodwill. The analysis shows that the logic of common law precedent, supported by statutes and academic commentary, points to a measure of special damages for reputational harm based on stock market data.

The result is helpful to a corporate plaintiff whose shares are publicly traded in an efficient market. A plaintiff who has to prove special damages typically faces a complex task. Proof of special damages is difficult, ${ }^{225}$ and special damages must be pleaded with specificity and proven with reasonable certainty. ${ }^{226}$ In some jurisdictions a plaintiff may not recover damages for defamation without

Theory to Measure Damages in Fraud on the Market Cases, 37 UCLA L. REV. 883 (1990); Mark L. Mitchell \& Jeffry M. Netter, The Role of Financial Economics in Securities Fraud Cases: Applications at the Securities and Exchange Commission, 49 Bus. L. 545 (1994).

225. See I SACK, supra note $3, \S 10.3 .2$ (stating "actual pecuniary loss resulting from defamation is typically difficult to establish"). See also Charles J. Faruki, The Defense of Terminated Dealer Litigation: A Survey of Legal and Strategic Considerations, 46 Онюо ST. L.J. 925, 994 (1985) (noting "damages for lost goodwill are difficult to quantify" (citing Agric. Serv. Ass'n v. Ferry-Morse Seed Co., 551 F.2d 1057, 1070-72 (6th Cir. 1977))).

226. See, e.g., Robertson v. McCloskey, 680 F. Supp. 414 (D.D.C. 1988) ("Specific evidence demonstrating the financial harm resulting from the libel is required before compensation for economic harm can be awarded."). See also FED. R. CIV. P. 9(g) ("If an item of special damage is claimed, it must be specifically stated."); Dobbs, supra note 40 , at 1143 (describing special harm as "specifically identified pecuniary harm resulting from the slander"). 
proof of special damages. ${ }^{227}$ This Article paves the way for an approach to proving and measuring special damages which significantly lightens a plaintiff's burden. The method can be implemented routinely by financial economists, applying standard statistical techniques to publicly available data.

227. See I SACK, supra note $3, \S 10.3 .2$ ("Depending on the law of the relevant jurisdiction, certain slanderous and libelous statements are not actionable at all, irrespective of the resulting injury to reputation, unless the plaintiff pleads and proves special damages." (citing David A. Anderson, Reputation, Compensation and Proof, 25 WM. \& MARY L. REV. 747, 748 (1984))). 
Notes \& Observations 